Oxford University

Centre for

Business Taxation

\title{
Destination-Based Cash Flow Taxation
}

\section{WP 17/01}

Alan Auerbach

University of California, Berkeley

Michael P. Devereux

Oxford University Centre for Business Taxation

Michael Keen

International Monetary Fund

John Vella

Oxford University Centre for Business Taxation

Working paper series | 2017 


\title{
Destination-Based Cash Flow Taxation
}

\author{
Alan Auerbach \\ University of California, Berkeley \\ Michael P. Devereux \\ Oxford University Centre for Business Taxation \\ Michael Keen \\ International Monetary Fund \\ John Vella \\ Oxford University Centre for Business Taxation
}

January 27, 2017 


\section{Preface}

This paper sets out a possible approach to the international taxation of corporate profit: a destination-based cash flow tax (DBCFT). This option is one of a number that have been considered over the last three years by a group of economists and lawyers, chaired by Michael Devereux. The other current members of the group are Alan Auerbach, Michael Keen, Paul Oosterhuis, Wolfgang Schön and John Vella.

The group's intention is to produce a book which provides an extensive discussion of alternative ways in which jurisdictions might tax a share of the profit of multinational companies, including the existing system and well-known alternatives such as formulary apportionment. The book will analyse in detail two reform proposals, a DBCFT and a "residual profit allocation", which is based more closely on the existing framework for taxing multinational profit. Members of the group presented both of these ideas in public conferences at Oxford University in June 2016, and at the Tax Policy Center in Washington DC in July 2016, as well as at other events in Europe and the USA.

In June 2016, the Ways and Means Committee of the US House of Representatives published a Blueprint document "A Better Way for Tax Reform", ${ }^{1}$ which proposes a version of a DBCFT. In the light of the public interest in this idea, the group has decided to publish this paper in advance of completing the book; in effect it is a draft of one chapter of the book. The intention of publishing this now is to help inform the public debate about the properties of a DBCFT, and to highlight and discuss issues that would arise in its implementation.

The paper shows that the DBCFT is equivalent in economic terms to a reform that introduces a broad-based, uniform rate VAT (or achieves the same effect through an existing VAT), and reduces taxes on payroll by the same proportion. Each of these two options has advantages and disadvantages in terms of implementation, which are set out and discussed in the paper.

The authors of this paper would like to thank several people who have contributed to their thinking about the DBCFT and other options, especially group members Paul

${ }^{1}$ https://waysandmeans.house.gov/taxreform/ 
Oosterhuis and Wolfgang Schön. We are also grateful to have received helpful comments from, among others: Rosanne Altshuler, Jennifer Blouin, Stephen Bond, Ian Brimicombe, Alex Cobham, Rita de la Feria, Steve Edge, Judith Freedman, Malcolm Gammie, Michael Graetz, Rachel Griffith, Itai Grinberg, Valeska Gronert, Michelle Hanlon, Chris Heady, Jim Hines, Vanessa Houlder, John Kay, Ed Kleinbard, Ben Lockwood, Mark Mazur, Peter Merrill, Will Morris, Paul Morton, Tom Neubig, John Samuels, John Sherman, Joel Slemrod, Eric Toder, Al Warren, David Weisbach and staff at the International Monetary Fund. The contents of this paper are the sole responsibility of the four named authors. Views expressed here should not be attributed to the IMF, its staff, Executive Board or its Management.

Devereux and Vella are grateful to the Nuffield Foundation for financial support.

For correspondence, please email michael.devereux@sbs.ox.ac.uk. 


\section{Executive Summary}

This paper presents, analyses, and further develops the idea of a destination-based cash-flow tax (DBCFT). Its purpose is expositional: to describe the DBCFT, how it might work, what its effects would be and some of the challenges that its implementation would face.

The DBCFT has two basic components.

- The "cash flow" element gives immediate relief to all expenditure, including capital expenditure, and taxes revenues as they accrue.

- The "destination-based" element introduces border adjustments of the same form as under the value added tax (VAT): exports are untaxed, while imports are taxed.

This is equivalent in its economic impact to introducing a broad-based, uniform rate Value Added Tax (VAT) - or achieving the same effect through an existing VAT - and making a corresponding reduction in taxes on wages and salaries.

The paper evaluates the DBCFT against five criteria: economic efficiency, robustness to avoidance and evasion, ease of administration, fairness and stability. And it does so both for the case of universal adoption by all countries and the more plausible case of unilateral adoption.

In contrast with existing systems of taxing corporate profit, especially in an international environment, the DBCFT and VAT-based equivalent have significant attractions:

- A central motivation for the DBCFT is to improve economic efficiency by taxing business income in a relatively immobile location - that is, the location of final purchasers of goods and services (the "destination"). The DBCFT should not distort either the scale or the location of business investment and eliminates the tax bias towards debt finance by assuring neutral treatment of debt and equity as sources of finance.

- Taxing business income in the place of destination also has the considerable advantage that the DBCFT is also robust against avoidance through inter-company 
transactions. Common means of tax avoidance - including the use of intercompany debt, locating intangible property in low-tax jurisdictions and mispricing inter-company transactions - would not be successful in reducing tax liabilities under a DBCFT.

Here however the distinction between universal and unilateral adoption is important. With adoption by only a subset of countries, those not adopting are likely to find their profit shifting problems to be intensified: companies operating in high tax countries, for instance, which may seek to artificially over-price their imports, will face no countervailing tax when sourcing them by exporting from related companies in DBCFT countries.

- By the same token, the DBCFT provides long term stability since countries would broadly have an incentive to adopt it - either to gain a competitive advantage over countries with a conventional origin-based tax, or to avoid a competitive disadvantage relative to countries that had already implemented a DBCFT. It would also be resistant to tax competition in tax rates.

In terms of its distributional impact, given the equivalence between a DBCFT and a VAT combined with a labour tax cut, the incidence of the tax would be on domestic residents financing consumption other than from wages, including from profit subject to the DBCFT. In that respect, the DBCFT would be more progressive than a single rate VAT, and possibly more so than existing corporate taxes (the burden of which may fall largely on labour). If desired, it would be possible to maintain a tax on the return to capital at the personal level, though the paper does not elaborate on this.

Fairness between countries is harder to assess, but - combined with taxes on natural resources - some very preliminary evidence suggests that few countries would be likely to see a reduction in their tax base as a result of border adjustment in itself.

The paper looks closely at the application of DBCFT treatment to the financial sector, which is a familiar problem under the VAT but has been little considered under the DBCFT. It compares two alternative approaches, based on the Meade Committee's 'Rbase' (taxing only "real" flows) and its ' $R+F$ ' base (taxing "real and financial") flows. There are shown to be equivalent for transactions between taxed entities. 
Administrative considerations suggest applying the $\mathrm{R}$ base to most companies, but also taxing financial flows between financial companies and tax exempt entities and individuals

The DBCFT raises a number of significant implementation issues - both administrative and legal - and requires substantial changes, both conceptually and in application, from current practice in corporate taxation. Neither of its two principal design features, a cash flow tax base and taxation on a destination basis, are commonplace amongst existing corporation taxes. Issues related to losses, familiar under the VAT, would be amplified. The paper sets out this and other core implementation issues, and how they might be addressed. It also compares the implementation of a DBCFT with the economically equivalent VAT-based approach, setting out the advantages and disadvantages of each.

One critical legal issue is that many have argued that the basic DBCFT, with an integrated relief for labour costs, is inconsistent with WTO rules. However, this is not true of the economically equivalent VAT-based approach, either on the usual invoicecredit basis, or on a subtraction method. It is also possible that the DBCFT would be considered to be within the ambit of bilateral income tax treaties, in which case it would clearly be inconsistent with several of the typical provisions of such treaties.

For any country, replacing a conventional corporate income tax by a DBCFT, or VATbased equivalent, would be a major undertaking. This paper considers core issues of design and implementation, but the assessment of any proposal must evaluate its details, including in relation to possible accompanying measures. Deviations from the design principles set out in the paper could alter significantly the analysis it provides and the conclusions that it reaches. For any proposal, careful, country-specific assessment of design, implementation and probable effects, including those for other countries, will be essential. 


\section{Destination-Based Cash-Flow Taxation}

This paper presents, analyses, and further develops the idea of a destination-based cash-flow tax (DBCFT). ${ }^{2}$

The DBCFT has several highly attractive properties: it does not distort the scale and location of investment, assures neutral treatment of debt and equity as sources of finance, is robust against avoidance through inter-company transactions, and provides long term stability due to its incentive compatibility and its resistance to tax competition amongst states. The DBCFT thus addresses many of the ailments afflicting current tax systems in both purely domestic and international settings.

On the other hand, the DBCFT raises a number of significant implementation issues both administrative and legal - and requires substantial changes, both conceptually and in application, from current practice in corporate taxation. Neither of its two principal design features, a cash flow tax base and taxation on a destination basis, are commonplace amongst existing corporation taxes. ${ }^{3}$

The purpose of this paper is expositional: to describe the DBCFT, how it might work, what its effects would be and some of the challenges its implementation would face. To this end, the paper starts by outlining how a DBCFT would work, and elaborating on its key elements, including the nature and role of border tax adjustments. We show too that a tax reform with equivalent economic effects would be to introduce a broad-based, uniform rate Value Added Tax (VAT) - or achieve the same effect by raising the rate of an existing VAT - and making a corresponding reduction in taxes on wages and salaries. Section 2 then evaluates the DBCFT on the basis of five criteria: economic efficiency, robustness to avoidance and evasion, ease of administration, fairness and stability. In doing so we deal in turn with two cases: that in which all countries adopt a DBCFT (or VAT-based equivalent) and that in which adoption is unilateral. Section 3 then considers the treatment of financial flows, from both conceptual and practical perspectives. This is as an important issue that has not

\footnotetext{
${ }^{2}$ For earlier discussions of the DBCFT, see Bond and Devereux (2002), President's Advisory Panel on Federal Tax Reform (2005), Devereux and Birch Sorensen (2006), European Economic Advisory Group (2007), Auerbach, Devereux and Simpson (2010), Auerbach (2010), Devereux (2012) and Auerbach and Devereux (2015). See also Avi-Yonah and Clausing (2016) and Cui (2016).

${ }^{3}$ The only national-level cash flow tax of which we are aware is the Mexican IETU, which operated (as a minimum tax) between 2007 and 2014, apparently without major technical difficulty.
} 
previously been considered in detail. Finally, Section 4 takes up a range of implementation issues, though the paper does not attempt a full treatment of all the issues that are likely to arise in practice (many of which are likely to be countryspecific). 


\section{THE DBCFT IN OUTLINE}

The DBCFT has two distinct attributes: a cash-flow tax base and a destination basis. A destination basis could be applied to a variety of tax bases, and arguments for cashflow taxation originally arose in a purely domestic setting. But there are advantages to combining the destination basis and the cash-flow tax base. This section recalls the features of a cash flow tax operating in a single economy, explains what destinationbasing would mean and what a DBCFT would look like, and shows its economic equivalence to the combination of a VAT and a reduction of taxes on labour by the same amount.

\section{Cash flow taxation}

Cash flow taxation in a single economy has been studied at length. ${ }^{4}$ As its name implies, a cash flow tax applies to net receipts arising in the business. Receipts are included in the tax base when payment is received and expenses are recognized when payment is paid. ${ }^{5}$ The tax base in any given period is the former less the latter. The most significant difference in the timing of the inclusion of receipts and expenses in the base, compared to most existing corporate tax systems, is that under cash flow taxation even capital assets that are typically depreciated over time are immediately expensed (i.e. deducted in full upon purchase). There is therefore no need for complex depreciation rules that are typically found under current systems, and no need to differentiate between different types of assets. This also introduces a significant difference between the cash-flow tax base and measures of profit in financial statements.

In the terminology of the Meade Committee (1978), a cash-flow tax could be levied on a company on an R (real) base or an R+F (real plus financial) base. Under the R base, transactions involving financial assets and liabilities are ignored - so, for example, interest receipts would not be taxed and interest expenses would not be deductible.

\footnotetext{
${ }^{4}$ The idea of the cash flow tax dates back to Brown (1948), and has since been the subject of an extensive literature that began with Kaldor (1955), Andrews (1974), US Treasury (1977), Meade (1978) and Graetz (1979). Readers familiar with properties of cash flow taxation in a closed economy can easily skip this subsection.

${ }^{5}$ More precisely, the tax would naturally be based on an accruals basis so that, for example, receipts are recorded when the obligation to pay is incurred, rather than when cash is actually received. The accruals basis would also apply to purchases, including of capital assets. Similar arrangements are common, of course, under the VAT.
} 
The $R$ base is thus limited to the difference between real inflows (from the sale of products, services and real assets) and real outflows (from the purchase of materials, products, services - including labour - and real assets). By contrast, under the R+F base, all cash inflows, including borrowing and the receipt of interest, would be taxable; all cash outflows, including lending, repaying borrowing and interest payments would be subtracted in calculating the tax base. That is, the tax would apply to all net financial inflows related to borrowing, including principal amounts, as well as to net real inflows. ${ }^{6}$ The choice between an $\mathrm{R}$ and an $\mathrm{R}+\mathrm{F}$ base is discussed in detail below.

The properties of the cash flow tax, conceived of as operating in a single economy, are well-known and so treated only briefly here. The starting point for understanding them is the usual assumption that an investor seeks to maximize the net present value (NPV) profit of an investment, measured as the sum of all discounted cash flows associated with it. The discounting effectively adjusts for interest that might otherwise have been earned during the intervening period. For instance, in the example below, assuming a discount rate of $10 \%$, a cash flow of 110 in one year's time has a present value of 100 . Since the discounting approach adjusts for a required rate of return on an investment, the NPV is a measure of the economic rent of an investment. In principle, it is worth undertaking any project with a NPV greater than zero; and it is not worth undertaking any project with a NPV less than zero. Any tax that falls only on economic rent (and has a rate between zero and $100 \%$ ) has the property that the post-tax NPV of an investment has the same sign as the pre-tax NPV. In this case, any investment worth undertaking in the absence of tax remains worth undertaking in the presence of tax, and vice versa. Hence the investment decision is independent of a tax on economic rent.

The example in Box 1 shows that a cash flow tax can indeed be thought of as a tax on the NPV, or economic rent, of an investment. Intuitively, cash flow taxation is neutral because, in effect, the government contributes a proportion of all costs of the business (through giving tax relief for all costs when they are incurred), and takes the same proportion of all receipts. In effect, the government becomes a shareholder in the business. Like other cases in which the ownership of shares in a business changes, this in itself has no effect on the profitability of the business, or on marginal

\footnotetext{
${ }^{6}$ The Meade committee discussed a third form: the ' $\mathrm{S}$ ' base cash flow tax, levied on net distributions to shareholders. As a consequence of the identity between a firm's sources and uses of funds, an S-base tax is precisely equivalent to an R+F-based one, at least in a domestic context.
} 
investment and financial decisions. By taxing all cash flows at the same rate, the government captures that same proportion of economic rent. ${ }^{7}$

\section{Box 1. Neutrality of cash flow taxation in a single economy setting}

Consider a two-period investment, with a cost of 100 in period 1, an interest rate of $10 \%$, and a tax rate of $20 \%$. Under a cash flow tax, there is a negative tax liability in period 1 of 20. In period 2 the investment makes a return. For an investment that just breaks even, the total value of the investment in period 2 must be 110: this represents a rate of return of $10 \%$, equal to the discount rate. The total return of 110 generates a tax liability in period 2 of 22. In NPV terms, the NPV pre-tax and post-tax are both zero. That is, the economic rent before and after tax are both zero. The tax also has a NPV of zero; that is consistent with the tax only falling on economic rent.

\section{Illustration of properties of a cash flow tax on investment incentives}

\begin{tabular}{|l|c|c|c|}
\hline & Pre-tax cash flows & Cash flow tax & Net cash flows \\
\hline Period 1 outflows & 100 & -20 & 80 \\
\hline Marginal investment & & & \\
\hline Period 2 inflows & 110 & 22 & 88 \\
\hline NPV, at 10\% discount rate & 0 & 0 & 0 \\
\hline Rate of return earned & $10 \%$ & - & $10 \%$ \\
\hline With economic rent & & & \\
\hline Period 2 inflows & 132 & 26.4 & 105.6 \\
\hline NPV, at 10\% discount rate & 20 & 4 & 16 \\
\hline Rate of return earned & $32 \%$ & - & $32 \%$ \\
\hline
\end{tabular}

In the lower part of the table, we assume instead that the investment generates a return of $32 \%$, that is, it is worth 132 in period 2. Combined with the initial outlay of 100, that represents a net present value of $20 .{ }^{8}$ Tax due in period 2 is 26.4 , implying that the NPV of the tax is 4 . That leaves a post-NPV of 16 . Since both the pre-tax and post-tax NPVs are positive, the investment is attractive to the investor irrespective of the tax. Note also, that the NPV of the tax is equal to $20 \%$ of the pre-tax NPV of the investment; so the tax is effectively a tax on the economic rent of the investment. That is why it does not affect the investment decision. This also implies that the post-tax rate of return (a return of 105.6 on a net investment of 80 ) is also $32 \%$ - the same as the pre-tax rate of return.

\footnotetext{
${ }^{7}$ Complications may arise in practice. For example, this simple characterisation assumes a symmetric tax system, in which the government collects tax when cash flows are positive, but effectively makes a tax rebate when cash flows are negative. The appropriate treatment of losses is discussed below in a number of different settings.

${ }^{8}$ The net present value of a cash flow arising in the next period is calculated by dividing the value of the cash flow by 1 plus the interest rate, expressed as a decimal. Thus, in this case, the NPV of 132 is $132 / 1.1=120$.
} 
The neutrality of cash flow taxation applies also to financial decision-making. Existing taxes on corporate profit generally treat debt and equity asymmetrically: the return on debt is generally deductible from the corporate tax base, whilst the return to equity is not. This favourable treatment of debt distorts the choice of financing between debt and equity financing, leading to leverage ratios that are higher than they would otherwise be. ${ }^{9}$ This is a significant concern: socially excessive levels of debt, especially in the financial sector, are widely seen as having played a central role in triggering and deepening the financial crisis of 2008.

By contrast, cash flow taxes, either with an $\mathrm{R}$ or an $\mathrm{R}+\mathrm{F}$ base, do not distort the choice between debt and equity. This is easily seen in the case of an $\mathrm{R}$ base, since all financial flows are simply ignored, be they associated with debt or equity. But the same applies to the $\mathrm{R}+\mathrm{F}$ base. We return to this issue in more detail below.

However, there are caveats to this analysis. One is that cash flow taxes lose their neutrality if the tax rate is expected to change over time: a falling rate will encourage investment, for instance, since the cost is deducted at a higher rate than it is later taxed. Second, even cash flow taxes may distort the choice between mutually exclusive projects which face different tax rates; the classic case in which this is a factor is in location choices between countries, as we discuss below, but this could also occur in a purely domestic context. Third, the analysis is based on the assumption that a business will aim to maximize its value, summarized by the NPV. This may not necessarily be the case. One possibility, for example, is that managers with a short term horizon will seek to maximize current profit as recorded in financial statements; this is more likely, of course, if managers' own remuneration depends on current financial earnings. In some cases, this may not be consistent with maximizing the NPV of the business. At various points in the discussion below of the precise design of the DBCFT, we consider this possibility.

It should be noted too that cash flow taxation is not the only way to achieve neutrality in business taxation. The same economic effects can in principle be achieved by giving relief for the cost of depreciation of assets, instead of an immediate write-off, and in addition giving relief for the cost of finance. In the case of debt finance, this cost is

\footnotetext{
${ }^{9}$ For a survey on the impact of the tax incentive to use debt, see Graham (2003). More recent evidence is provided by, amongst others, Devereux, Maffini and Xing (2016), Doidge and Dyck (2015), Heider and Ljungqvist (2015) and Keen and de Mooij (2015).
} 
normally the interest payments that the business must make on its borrowing. For equity finance, it is an opportunity cost, reflecting the return that the shareholder has foregone on some alternative asset of equivalent risk. These financial costs can be seen as reflecting a minimum rate of return that the providers of finance require on their investments in the business. Naturally, then, giving relief for these costs implies that only economic rent - that is, profit over and above the minimum required rate of return - is subject to tax.

Comparing this approach to cash flow treatment, relief for the opportunity cost of finance can also be seen as compensating for the lack of immediate expensing in the system. Giving relief only for the depreciation of capital assets in effect defers tax relief on capital expenditure relative to a cash flow tax. Relief for the opportunity cost of capital compensates for this deferral. In fact, as the IFS Capital Taxes Group (1991) showed, it is possible for a tax to fall on economic rent with any schedule of depreciation allowances, as long as relief for the opportunity cost of capital is based on the difference between the initial cost of the asset and its tax-depreciated value. The IFS Capital Taxes Group proposed an "Allowance for Corporate Equity" (ACE) based on this principle, which would be a relief in addition to relief for the cost of interest payments. ${ }^{10}$

The approach using an ACE has the advantage of being more similar to existing corporation taxes, in that it simply adds one additional relief and leaves features like interest deductibility and capital allowances unaffected. It has the disadvantage of adding some complexity relative to the cash flow tax, since it requires the specification of a rate at which the allowance is applied, although this has been applied in practice in the context of ACE reliefs introduced in several countries, ${ }^{11}$ and also in resource taxes.

\section{Destination basis}

The international setting introduces the second dimension of the DBCFT, relating to how a country determines the component of a corporation's tax base falling within its

\footnotetext{
${ }^{10}$ The equivalence of expensing and a rate of return allowance was first shown by Boadway and Bruce (1984). Kleinbard (2007) proposes a related form of cost of capital allowance. Bond and Devereux (1995, 2003) analyse the properties of various such rate of return allowances in the presence of risk.

${ }^{11}$ For example, in Austria, Belgium, Brazil, Croatia, and Italy. Experience with the ACE is reviewed in de Mooij (2011); see also Zangari (2014) and IMF (2016a).
} 
particular jurisdiction. A DBCFT would be based on sales of goods and services in the country less expenses incurred in the country: so receipts from exports are not included in taxable revenues and imports are taxed. ${ }^{12}$ This 'border adjustment' is essentially the same treatment as is common under VAT; we explore differences from and similarities with VAT below. In a sense, the DBCFT would tax inflows and outflows asymmetrically - since income from sales are subject to tax in the place of the sale (the "destination" country), while expenses, including for labour, receive tax relief where they are incurred (the "origin" country). It thus combines both destination and origin elements. We stick, however, with the established terminology, with the term "destination" - taken from the literature on VAT-highlighting the role of border adjustment on payments and receipts.

A simple example makes the workings of the DBCFT clear (Table 1). Suppose a company produces goods in country A, employing labour at a cost of 60 and with costs of 40 on other domestic purchases. It sells goods to domestic consumers in A for 150 , and also has exports goods to country $B$ of 150 . It therefore has a total profit, in cash flow terms, of 200.

Table 1. Illustration of application of the DBCFT

\begin{tabular}{|l|c|c|c|}
\hline & Country A & Country B & Total \\
\hline Tax rate & $20 \%$ & $30 \%$ & \\
\hline Labour costs & 60 & 0 & 60 \\
\hline Other costs & 40 & 0 & 40 \\
\hline Sales & 150 & 150 & 300 \\
\hline DBCFT tax base & 50 & 150 & 200 \\
\hline DBCFT charge & 10 & 45 & 55 \\
\hline VAT tax base & 110 & 150 & 260 \\
\hline VAT charge & 22 & 45 & 67 \\
\hline $\begin{array}{l}\text { Relief for labour } \\
\text { costs }\end{array}$ & -12 & 0 & 55 \\
\hline $\begin{array}{l}\text { VAT }+ \text { relief for } \\
\text { labour costs }\end{array}$ & 10 & 45 & \\
\hline
\end{tabular}

\footnotetext{
${ }^{12}$ More precisely (and as discussed later): imports by businesses liable to a DBCFT could either be taxed, with a deduction then available, or untaxed but not deductible; imports by final consumers would simply be taxed.
} 
The DBCFT tax base in country $A$ is calculated as domestic sales of 150 less domestic cost of 100: a total of 50 . The DBCFT tax base in $B$ is simply the value of the imports into $B: 150$. If the tax rate in $A$ is $20 \%$ and that in $B$ is $30 \%$, then the firm's tax liabilities are 10 in $A$ and 45 in $B$.

The relevant "destination" for the calculation of tax, it should be emphasized, is the location of the immediate purchaser, not (necessarily) that of the final consumer. For example, if a US manufacturer sells steel to a French automobile producer which uses the steel to produce automobiles sold back to the United States, US application of the destination-based tax would not tax the sale of steel but would tax the automobile imports.

It is, however, the location of the final consumer upon which the impact of the DBCFT ultimately turns. Sales to other businesses effectively attract no tax under the DBCFT, either (if the sale is domestic) because they generate a deduction for the purchaser or (if exported) because they are untaxed. Thus the DBCFT, as will be seen more clearly below, is built on the intuition that taxing companies on the basis of something that is relatively immobile - which, by and large, we take consumers to be - limits the scope for the gaming that has caused such difficulties within the current international tax framework.

It should be noted too that other forms of rent tax, other than cash flow taxes, could also be destination-based. One could also implement border adjustments under an ACE, for example, though this would raise additional considerations. For instance, it will be seen below that one advantage of the cash flow approach to destinationbasing is that tax frequently nets out to zero. An example is the taxation of an import of capital assets used by business, where under a cash flow tax, the tax on the import nets out with the tax relief for the cost of the input. In effect this means that the import can be ignored except to the extent that enforcement requires that they are not passed off as domestic purchases, which would receive relief on the grounds that tax had already been paid on the purchase from the domestic supplier. This is not true under the ACE, where the capital asset would initially receive only a depreciation allowance. 
3. Equivalence between the DBCFT and a VAT with matching reduction in wage taxes

Before turning to an evaluation of the DBCFT, it is useful to compare the DBCFT with a VAT. In the example in Table 1 above, under the usual invoice-credit method, at a tax rate of $20 \%$, the company would remit VAT on the value of the domestic sale (30) net of the VAT already paid on the non-labour input (8). ${ }^{13}$ The total VAT payment by the company in A would thus be 22 . The VAT due in $B$, where there are only sales, ${ }^{14}$ would be the same as the DBCFT charge, 45 .

The only difference in principle between the DBCFT and a VAT is in the treatment of labour costs. In $B$, where no wage costs are incurred, the liability is the same under the DBCFT as under the VAT. In A, the difference in the DBCFT base and the VAT base is the 60 of labour costs incurred in A. The DBCFT is intended to tax profit, and so gives relief for labour costs. The VAT is intended to tax value added; this is equivalent to the sum of profit and the amount paid to labour, and so VAT does not give relief for labour costs. It follows that introducing a VAT (or increasing its rate) - having in mind here an idealized VAT, levied at a single rate on a broad base ${ }^{15}$ - and reducing labour income taxes at the same rate would have equivalent economic effects to those of the DBCFT. This is shown in the last two lines of the table: giving relief for labour costs in $A$ reduces the tax in $A$ by 12 , and the combination of the VAT and relief for labour costs yields the same tax base as the DBCFT.

Below we discuss in some detail the two options of (a) implementing a DBCFT as a reform to corporation tax, and (b) an economically equivalent reform of introducing a VAT (or applying an increased rate to the generality of transactions under an existing VAT) combined with a matching reduction in taxes on wages and salaries.

\footnotetext{
${ }^{13}$ The standard invoice-credit method of collecting VAT keeps track of VAT on every transaction. A VAT registered business remits tax on its sales less the VAT it has paid on its inputs. A subtraction-method VAT is more akin to a corporation tax - and the DBCFT - with annual accounting of the sales less nonlabour costs made by the company. In the simple case in which there is a single VAT rate, these approaches result in the same tax base.

${ }^{14}$ Importation of the 150 from the entity in country A would be subject to VAT, but a credit of exactly the same amount would be available against the VAT due on sales.

${ }^{15} \mathrm{~A}$ qualification that, for brevity, we shall often omit below.
} 


\section{Border Adjustments ${ }^{16}$}

A key element for understanding both the incentive effects of a DBCFT and the incidence of a DBCFT is the role played by border tax adjustment (BTA). By this is meant that exports would not be subject to the tax, but imports would be. The impact of BTA has been extensively studied in the literature on VAT, in analysing the effects of shifting from an origin-based system (export taxed, imports untaxed) to a destination-based system (exports untaxed, imports taxed); we draw on that literature here.

The adoption of border adjustments would appear initially to make a country more competitive in international trade. But any such effect is at most a temporary one.

To see this, consider first the case in which there is a single common currency, or a fixed exchange rate. Then consider a border adjustment by one country only; for the moment we consider only the impact of this border adjustment, abstracting from the other elements of the DBCFT. ${ }^{17,18}$ Moving from an origin-based tax that included exports in the tax base, the border adjustment would make exports cheaper on the world market; this would create a stimulus to exports. By contrast, the domestic cost of imports would increase with the tax on imports; this would discourage imports. With a fixed exchange rate, and sticky wages, both effects would induce a stimulus to domestic activity. This corresponds to the well-known effect of such border adjustments having the same impact as a currency devaluation - that is, in making exports cheaper to non-domestic consumers, and imports more expensive for domestic consumers. ${ }^{19}$ In the short run, this would generate a stimulus to domestic production relative to foreign production.

Over the longer run, however, we would expect prices to adjust. Expansion of domestic production would lead to an increase in the demand for labour. This would

\footnotetext{
${ }^{16}$ See Auerbach and Holtz-Eakin (2016) for an elaboration of, and examples illustrating, the arguments in this subsection.

${ }^{17}$ As discussed below, alternatively consider the case of a switch from an origin-based cash flow tax to a destination-based cash flow tax; this would give the same effect, reducing the tax on exports, and increasing the tax on imports.

${ }^{18}$ The analysis here is in the context of the border adjustment taking place in a single country. If it happened in several countries at once, then the effects identified would be replicated in each country. The extent of price and/or exchange rate adjustments would depend on relative tax rates in the countries undertaking the reform.

${ }^{19}$ First pointed out by Keynes (1931).
} 
in turn push up the wage rate, and in consequence, push up the price of domestically produced goods and services. The effect of this rise in prices and wages would be to begin to raise again the price of exports on the world market, and to raise the price of domestically-produced goods relative to imports. When domestic prices and wages had risen far enough, the initial real equilibrium will be re-established. ${ }^{20}$ In this long run, there would be no overall impact on trade, due to the price adjustments.

If instead the country had a flexible exchange rate, the same real long-run effect would occur naturally - and much more quickly, quite possibly indeed immediately (with some effect in advance if the change is pre-announced) - through an appreciation of the exchange rate, which would raise the (domestic currency) price of exports in the world market and reduce the price of imports. This would not require adjustment to the nominal price level in the domestic country. ${ }^{21}$ In effect, the initial fiscal devaluation would immediately be offset by an appreciation of the currency i.e. a revaluation; these two effects would cancel out, leaving trade unaffected.

The nature of the adjustment - as between changes in domestic prices and wages, in the nominal exchange rate, and in the level of activity - will thus depend in practice on which of these can adjust more rapidly. There is, it may be helpful to note, an important difference here between the adoption of a DBCFT and the adoption of a VAT. Under the latter, consumer prices rise relative to wages, an effect that cannot be accomplished simply by a change in the nominal exchange rate; with wages sticky, the expectation is that the effect will come largely through an increase in consumer prices. The DBCFT, however, leaves that relative price unchanged, and so can be transmitted through the exchange rate.

The precise conditions under which - as a consequence of adjustment in the exchange rate and/or domestic prices - the shift from an origin to a destination basis will have no impact on the real equilibrium have been extensively studied in the VAT

\footnotetext{
${ }^{20}$ See Auerbach and Devereux (2015).

${ }^{21}$ It is important to distinguish these effects of the DBCFT from its effects on the levels of wages, prices and exchange rates, even though the concepts are related. The impact on the general price level is a macroeconomic phenomenon related to monetary policy, exchange rate policy, the nature of bargaining in the labour market, and domestic price-setting behaviour, and in itself tells us relatively little about the effects of the tax.
} 
literature. ${ }^{22}$ And, since wages are deductible in both cases, these results apply directly to the comparison between a destination - and origin - based cash flow tax.

The conditions required for such an equivalence between a destination- and originbased cash flow tax, it should be stressed, are demanding. One necessary condition is that a uniform tax rate applies to all sectors: without this, adjusting only the exchange rate or simply rescaling process by some common factor cannot re-establish the prereform pattern of relative prices. Equivalence is unlikely to hold, for instance, if there is a large untaxed sector, or significant variation in business tax rates across sectors, or in respect of real-world VATs for which rate differentiation is commonly extensive. ${ }^{23}$ The wider political economy of taxation clearly plays a role here. Nor does the result hold with imperfect competition. ${ }^{24}$ There is, however, little work on the quantitative extent to which plausible violations of uniformity are likely to cause departures from equivalence.

It should be noted too that whilst in the simplest models it is immaterial whether it is domestic prices or the nominal exchange rate that adjusts, this does matter for precisely who is affected by BTA. Nominal exchange rate changes will have balance sheet effects for non-residents with assets or liabilities (or contracts) denominated in the currency of the DBCFT-adopter for example, which is some cases would be significant; domestic prices changes do not. The incidence of the DBCFT is discussed more fully below.

Account also needs to be taken on the impact of Border Tax Adjustment (BTA) on revenue. ${ }^{25}$ For countries running a trade deficit - imports exceeding exports - the shift to a destination basis will increase tax revenue. If trade is balanced in the long run, however, and the tax rate is expected to remain unchanged, the revenue impact in present value is zero, except to the extent of net imbalances prior to enactment. If consumers are sufficiently forward-looking to recognize this, there will then be no real impact from this revenue effect. More generally (and plausibly), however, there may

\footnotetext{
22 A comprehensive analysis is provided by Lockwood (2001), synthesizing a number of earlier contributions, including de Meza et al (1994) and Lockwood (1993).

${ }^{23}$ Feldstein and Krugman (1990) stress and explore the trade implications of departures from uniformity of the VAT.

24 The implications of imperfect competition for the comparison between origin and destination principles for indirect taxation are considered in Keen and Lahiri (1998).

${ }^{25}$ Assuming other conditions for equivalence to be met, this revenue impact is essentially an income effect across national borders, and does not affect the economic efficiency of the outcome reached.
} 
be an impact. Governments that are credit-constrained, for example, will not be indifferent to the timing of their tax revenues; and consumers may not be - though its nature is imponderable, depending, for instance, on the use made of the revenue and on consumers' preferences.

All these (and other) qualifications mean that the adjustment to the introduction of a DBCFT in practice may well not be as simple - even in the long run, and leaving aside potentially significant short-run effects - as some combination of a rescaling of domestic prices and appreciation of the nominal exchange rate. To the extent that this raises revenue, for instance, the impact will depend on what use is made of that additional revenue, on how interest rates react and on how consumers respond. It is important too to bear in mind that the discussion above has considered the introduction of a DBCFT in isolation, not in replacement of an existing corporate (or other) tax. That would of course bring additional considerations. For instance, moving to cash flow tax from a traditional corporate tax would be expected to ease disincentives to investment, creating a source of efficiency gain itself. Macro simulation methods can potentially provide more nuanced assessments of practical reform proposals, though of course subject to their own limitations. The key point, however, is that the considerations raised by the basics of BTA are likely to be of first order importance in assessing the impact of practical reforms.

One might hope to be able to draw on past experiences to gauge the likely impact of destination-basis taxation. But there is, unfortunately, very little empirical evidence on the effects of BTA (or of significant tax changes more generally) on exchange rates largely because these are rarely fundamental enough, relative to all the other factors that buffet exchange rates, to create reasonable prospect of being found in the data. There are, however, signs of effects along the lines just described in the work of de Mooij and Keen (2013) on 'fiscal devaluations.' These are tax changes that combine an increase in VAT and a reduction in the employers' social contributions ${ }^{26}$ on labour which, recalling the discussion in Section I.3, is much the same thing as an increase in the rate of a DBCFT. This was advocated by some as a way to stimulate activity in the Eurozone, mimicking the effects of the devaluation that was unavailable to them, until offset by upward movements of prices and wages as described above. Looking at 30 OECD countries between 1965 and 2009, what emerges is that there is indeed a

\footnotetext{
${ }^{26}$ The reason for focusing on the employers' contribution is that wage stickiness is most likely to apply to the wage net of those contributions, so that a cut translates immediately into reduced employment costs.
} 
marked short-term boost to net exports within the Eurozone countries and period. Outside the Eurozone, however, there is no effect - suggesting that adjustment to what resembles close to a DBCFT comes very quickly when the exchange rate is allowed to react. Where the exchange rate is fixed, recent evidence that increases in the standard rate of VAT are fully passed on to consumers fairly quickly - in about 6 months ${ }^{27}$ - suggest that it is rigidity in nominal wages that is most likely to account for extended adjustment periods.

There are two other respects, not addressed in these analyses, in which origin and destination taxation fundamentally differ. First, as set out below, a DBCFT should not affect the location of investment projects, whereas an origin-based cash flow tax generally would. Second, origin taxation, but not destination taxation, is vulnerable to transfer pricing abuse, since the prices charged on cross-border intermediate transactions affect overall tax liability. ${ }^{28}$ Under origin taxation, the seller charges tax at the rate of the exporting country but the buyer then takes a deduction at the tax rate of the importing country; if the rate charged on sales exceeds that on purchase, there is an incentive in transactions between related parties to set an artificially low price, and conversely if it is less. Under destination taxation, in contrast, neither country charges tax on such sales. And so, as will be amplified later, BTA removes a wide range of avoidance possibilities. ${ }^{29}$

\footnotetext{
${ }^{27}$ Benedek and others (2016).

${ }^{28}$ The point is stressed by Auerbach and Devereux (2015) in the context of cash flow taxation; see also Genser and Schulze (1997) in the VAT context.

${ }^{29}$ This is a major reason to prefer a DBCT over an origin-based cash flow tax even when the conditions of the standard equivalence results are met.
} 


\section{EVALUATING THE DBCFT}

We evaluate the properties of the DBCFT in two settings. The first is that in which the DBCFT is adopted by all countries, although - importantly - not necessarily at the same rate. The second is that in which it is adopted by just one. Our main discussion relates to the former case. Considering the properties of the DBCFT if introduced in a single country, or small group of countries, is critical, however, for the issue of whether individual countries might find it in their own interest to adopt the DBCFT, or whether it could only be introduced by significant agreement between countries. This issue is also important for its stability; for example, is there an incentive for an individual country to introduce the DBCFT if other countries have already adopted it; or are countries that have already adopted it likely to undermine it through competition?

The evaluation is by five criteria: economic efficiency, robustness to avoidance and evasion, ease of administration, fairness and stability. The first four of these are common criteria for evaluating taxes. By stability we mean that there is an incentive for a country to adopt a system, whether or not other countries adopt it, and that there would also be no incentive for a country to compete with others by changing the basic system or by cutting the tax rate, each of which could impose costs on other countries and thereby undermine the overall international system. In a subsequent section we address issues of implementation in more detail, here we focus on economic principles.

\section{Universal adoption}

\section{a. Economic efficiency}

In principle, the DBCFT has remarkable properties in terms of economic efficiency. In particular, it should not distort the scale or location of investment, nor forms of financing choices. We discuss each in turn.

\section{Location of investment}

Whilst taxes on economic rent should not distort marginal investment decisions in a domestic setting, once we move to an international setting such taxes can distort 
decisions on the location of investment if imposed on an origin basis - that is, broadly where the economic activity, or production defined very widely, takes place. This decision would be distorted, for example, if the states operating a tax on economic rents on an origin basis offer different tax rates. Faced with the decision where to locate their investment, the difference in tax rates may be so large as to induce companies to locate in the location which is less advantageous from a non-tax perspective. More generally, a difference in average tax rates on different mutually exclusive options may induce distortions, even if the tax base is economic rent. ${ }^{30}$

That distortion does not arise, however, if taxes on economic rent are levied on a destination basis. To see this, we have to consider the tax levied on the income generated from sales and the tax relief available for expenses. A key reason for choosing a destination basis is that consumers are relatively immobile; they are unlikely, except in some specific circumstances, to move in response to a higher rate of DBCFT. But it might be thought that there would be an advantage to locating expenses in a country with a high tax rate. By doing so firms would deduct expenses from profits which would otherwise be taxed at a high rate of tax (or, if in loss positions, they would receive relief at this high rate of tax). This is true - but the effect is negated by the impact of the border adjustments described above.

To see this, consider the example in Table 2. In Panel A, sales and costs in the two countries are as in Table 1, with the exchange rate between the two countries taken to be one-for-one. Initially, the two countries levy their DBCFTs at the same rate, 10 percent, which leaves the firm with after-tax profits of 180 . From the point of view of the firm, the situation is just as if it operated in a single economy with a single DBCFT of 10 percent. This means, in particular, and just as discussed there, that the firm's investment (and financing) decisions are wholly unaffected by the presence of the two taxes.

Suppose now that country $B$ raises the rate of its DBCFT to 25 percent. If nothing else changes, this, as seen in Panel B, increases the firms' total tax charge by 22.5 (15 percent of the base of 150 in country B), leaving it after-tax profits of 157.5.

\footnotetext{
${ }^{30}$ This assumes that the rent at issue is not specific to a particular location. See Devereux and Griffith (1998) for empirical evidence on the role of effective average tax rates on location decisions, and Auerbach and Devereux (2015) for a theoretical analysis.
} 
Table 2. Investment Neutrality of the DBCFT with universal adoption

Panel A

\begin{tabular}{|l|c|c|c|}
\hline & Country A & Country B & Total \\
\hline Tax rate & $10 \%$ & $10 \%$ & 60 \\
\hline Labour costs & 60 & 0 & 40 \\
\hline Other costs & 40 & 0 & 300 \\
\hline Sales & 150 & 150 & 200 \\
\hline DBCFT tax base & 50 & 150 & 20 \\
\hline DBCFT charge & 5 & 15 & 180 \\
\hline Net profit & 45 & 135 & \\
\hline
\end{tabular}

Panel B

\begin{tabular}{|l|c|c|c|}
\hline & Country A & Country B & Total \\
\hline Tax rate & $10 \%$ & $25 \%$ & 60 \\
\hline Labour costs & 60 & 0 & 40 \\
\hline Other costs & 40 & 0 & 300 \\
\hline Sales & 150 & 150 & 200 \\
\hline DBCFT tax base & 50 & 150 & 42.5 \\
\hline DBCFT charge & 5 & 37.5 & 157.5 \\
\hline Net profit & 45 & 112.5 & \\
\hline
\end{tabular}

Panel C

\begin{tabular}{|l|c|c|c|}
\hline & Country A & Country B & Total \\
\hline Tax rate & $10 \%$ & $25 \%$ & 60 \\
\hline Labour costs & 0 & 60 & 40 \\
\hline Other costs & 0 & 40 & 300 \\
\hline Sales & 150 & 150 & 200 \\
\hline DBCFT tax base & 150 & 50 & 27.5 \\
\hline DBCFT charge & 15 & 12.5 & 172.5 \\
\hline Net profit & 135 & 37.5 & \\
\hline
\end{tabular}

Panel D

\begin{tabular}{|l|c|c|c|}
\hline & Country A & Country B & Total \\
\hline Tax rate & $10 \%$ & $25 \%$ & 72 \\
\hline Labour costs & 0 & 72 & 48 \\
\hline Other costs & 0 & 48 & 330 \\
\hline Sales & 150 & 180 & 210 \\
\hline DBCFT tax base & 150 & 60 & 30 \\
\hline DBCFT charge & 15 & 15 & 180 \\
\hline Net profit & 135 & 45 & \\
\hline
\end{tabular}


Panel E

\begin{tabular}{|l|c|c|c|}
\hline & Country A & Country B & Total \\
\hline Tax rate & $10 \%$ & $25 \%$ & 60 \\
\hline Labour costs & 60 & 0 & 40 \\
\hline Other costs & 40 & 0 & 330 \\
\hline Sales & 150 & 180 & 230 \\
\hline DBCFT tax base & 50 & 180 & 50 \\
\hline DBCFT charge & 5 & 45 & 180 \\
\hline Net profit & 45 & 135 & \\
\hline
\end{tabular}

But, still assuming no other changes, the increased tax rate in $B$ gives the firm an incentive to shift its production there from $A$ to $B$, since that higher tax rate means $a$ larger deduction for costs. As shown in Panel $C$, shifting production in this way reduces the firm's total tax liability, and so increases its after-tax profit, by 15 (the difference in tax rates, 15 percent, multiplied by production costs of 100$)$.

If the tax rate change applied only to this firm, which was just one among many, that would be the end of the story. But if it applies to the generality of businesses, things will change, along the lines discussed in Section 1.4 above. As the demand of residents of $B$ for imports from $A$ falls (and the demand of residents of $A$ for exports from $B$ rises) upward pressure emerges-as described above-on the value of $B$ 's currency ${ }^{31}$ (or on wages and prices in $B$, if $A$ and $B$ have a fixed exchange rate). This has the effect, shown in Panel $D$, of increasing the value of profits earned in $B$ expressed in $A^{\prime} s$ currency, and rising by a factor (of 1.2 in this example) ${ }^{32}$ that reflects the difference in tax rates. Profits in B, expressed in A's currency, rise to 60, which, after tax at 25 percent, exactly restores after-tax profits to the level they had before the tax change and when all production was in A. Moreover, as shown in Panel E, the rise in B's prices also eliminates the firm's incentive to shift production to $B$, as maintaining production in A also results in after tax profits of 180 , rather than the 157.5 shown in Panel C.

\footnotetext{
${ }^{31}$ One can also think of the incipient capital inflow into $B$ described in the previous paragraph and the incipient net export surplus of $B$ described here as implying an excess demand for $B^{\prime}$ s currency in the foreign exchange market that is eliminated by a nominal appreciation of B's currency.

32 Denoting the tax rate in country $i$ by $T_{i}$, the adjustment required is $\left(1-T_{A}\right) /\left(1-T_{B}\right)$, which is $\mathrm{n}$ this example is $(1-0.1) /(1-0.25)=1.2$. Note that this adjustment does not depend on the firm's costs, sales or any other characteristics-and hence offsets the tax change for all firms. What is required for neutrality, however, is that the same rate apply to all firms in either country.
} 
The idea that prices and/or the exchange rate will adjust so as to exactly neutralize differences in rates of DBCFT across countries, it should be stressed, is not fanciful or arbitrary. The point, as is clear from the earlier discussion of BTA, is that if the initial situation is an equilibrium - firms and consumers all content with whatever it is they are doing - then so is that in which prices and/or the exchange rate have adjusted as described. Indeed unless there are some other equilibria, the adjustment must be of exactly this form.

If the exchange rate is fixed or managed, however, or if wages or prices are sticky, this adjustment may not come about instantaneously. Without the equilibrating appreciation of B's current or increase in prices and wages, B's exports will be cheap abroad and its imports expensive at home. Its net exports, and the level of activity, will therefore tend to rise. As the pressures on wages and prices this creates build up, however, the effect would be expected to be temporary.

Scale of investment

That the level of investment is also undistorted when all countries apply a DBCFT, at whatever rate, follows from the arguments just given. We have just seen that the presence of a DBCFT in country B, at whatever rate, left the firm's after-tax profit exactly as it was when it faced a 10 percent DBCFT everywhere. But when it faces such a tax, then, by the general property of cash flow taxation shown in Box 1, its investment decision is entirely undistorted.

\section{Form of financing}

Under an R-based cash flow tax, whether origin- or destination-based, financial flows simply do not enter the tax calculation and so are evidently left undistorted. The same is true under an $\mathrm{R}+\mathrm{F}$ base, given price and/or exchange rates of the kind analysed above.

\section{b. Robustness to avoidance and evasion}

No tax system is perfectly robust to avoidance and evasion. However, when adopted universally the DBCFT closes the most significant avoidance channels found under existing tax systems: it simply does away, in particular, with many of the problems 
currently besetting the taxation of multinationals, cutting through the swathe of issues taken on in the G20-OECD project on Base Erosion and Profit Shifting (BEPS).

When adopted in all countries, the DBCFT eliminates the shifting of profits to low-tax countries through the three most important current channels: lending from a low-tax country to a high-tax country, locating intangible assets that earn a royalty or license payment in a low tax country, and manipulating transfer prices.

The most straightforward of these to explain is debt shifting. Under an R-based cash flow tax, there is no tax relief for interest payments and there is no tax on interest received. So the debt-shifting channel simply would not exist. Lending among affiliates of a multinational located in different countries would simply have no tax consequences. As we set out below, this channel would not exist under the R+F base either.

Profit shifting through the manipulation of intra-group prices is also precluded by the DBCFT. To see this, consider the effect of a sale of a good by company $A$ to another member of the same multinational group, company $B$, with the two companies located in different countries. Under current arrangements, A pays tax on the sale of the good to $B$, but $B$ receives tax relief on the purchase of the good as an input into its own activity. If A's country has a higher tax rate, then there is an incentive to understate the true price of the good; B's tax relief on the purchase of the good will then exceed the tax levied on A's sale. If A's country has a lower tax rate, then the incentive is reversed; overall tax is lowered if the price is overstated.

But under a DBCFT, A faces no domestic tax on its export. B does face a tax on its import, ${ }^{33}$ but as an input into whatever activity $B$ is undertaking the cost of the good will also be deducted from B's tax base. These two effects exactly cancel out, making the value of the import irrelevant for tax purposes.

An alternative approach to implementing this treatment of imports, as discussed in Auerbach (2010) and further below, would be simply to exclude imports by taxable businesses from the tax base altogether - so that for them there is neither a tax on

\footnotetext{
${ }^{33}$ There is a need to define what is an import. The key issue here is that all goods sold domestically should be subject to the tax. Broadly, in this case, an "import" would be a good or service sold by an entity not subject to the domestic DBCFT (and also not a domestic entity excluded from it by virtue of size, as we discuss below in the context of the scope of the tax).
} 
imports, ${ }^{34}$ nor a deduction for the cost of the imported good. In this case, the transaction between $A$ and $B$ is entirely free of tax. Under this alternative approach, it is particularly easy to see how the destination basis eliminates certain tax avoidance opportunities based on mispricing of within-group cross-border transactions. Because cross-border transactions would simply no longer affect the tax base for either of the parties to the transaction, a company cannot influence its domestic tax liability by misstating revenues or expenses associated with cross-border transactions.

Table 3 illustrates this key point that - given universal adoption of a DBCFT, albeit at different rates in different countries - understating or overstating intra-group prices makes no difference to the overall tax liability under the DBCFT. The company imports the good from an affiliate in the same multinational group, and then sells it to a domestic third party - for example, a final consumer or an unrelated party - for a price of 120 . Both countries operate a DBCFT, and so there is no tax on the export in the exporting country. The tax in the importing country - assumed to be at $25 \%$ - can be thought of in two ways, as described above. In column (a) the import is taxed, and the cost of the import set against the tax charge on the sale to the final consumer. In column (b), the import is ignored for both purposes.

Suppose that the price at which the good is imported is 100 . Then under method (a), there is a tax charge on the import of 25 . In addition, there is a tax charge on the profit of the importing company at $25 \%$ of sales less imports - a tax liability of 5 . Total tax is therefore 30. Under method (b), the import is simply ignored, and there is a tax charge on the total value of the sale to the domestic consumer, which also generates a total tax liability of 30 . This shows the irrelevance of the import price of the import for the total tax charge. Even if the price were set to zero, or 120, the total tax charge would remain 30 .

The netting out of business-to-business transactions also makes the DBCFT robust to avoidance strategies used in the context of formulary apportionment systems which are based on the destination of sales. ${ }^{35}$ Under a formulary apportionment system, a highly profitable company could sell its products in a fully arms-length transaction to a much less profitable retail company in a low-tax jurisdiction. As a result, only the low rate of tax would be applied to the company's high profits. The retail company could

\footnotetext{
${ }^{34}$ Imports by final consumers would remain taxable.

${ }^{35}$ By this is meant a system under which the consolidated profits of a multinational are allocated for taxation across jurisdictions according to the share of each in its total sales.
} 
sell on the goods into a high tax jurisdiction and face tax at a higher rate, but this would only apply to its relatively low profit. The overall tax liability may then be considerably lower than if the original company had sold directly into the high tax jurisdiction. This would not happen under a DBCFT. In that case, the full value of imports into the final country of destination would be subject to tax in that country.

Table 3. DBCFT liabilities in importing country, with different prices for imports

\begin{tabular}{|c|c|c|c|}
\hline & Price & $\begin{array}{c}\text { Tax liability: } \\
\text { Method (a) }\end{array}$ & $\begin{array}{c}\text { Tax liability: } \\
\text { method (b) }\end{array}$ \\
\hline Import & 100 & 25 & 0 \\
\hline Sale to domestic consumer & 120 & 5 & 30 \\
\hline Total tax liability & - & 30 & 30 \\
\hline Import & 0 & 0 & 30 \\
\hline Sale to domestic consumer & 120 & 30 & 30 \\
\hline Total tax liability & - & 30 & 0 \\
\hline Import & 120 & 30 & 30 \\
\hline Sale to domestic consumer & 120 & 0 & 30 \\
\hline Total tax liability & - & 30 & \\
\hline
\end{tabular}

A third common strategy for profit shifting under the existing system is to place highly valuable intangibles in low tax jurisdictions. Other companies within the multinational group that are located in high tax countries may then pay royalties or license fees to the company that owned the intangible asset in return for their use. These payments receive tax relief at the high rate of tax and are liable to tax on the receipt at the low rate of tax. Again, this would not happen under a DBCFT.

The reason is the same as that given above. The purchase or sale of the right to make use of the intangible asset would naturally be treated in the same way as the purchase or sale of a good. This is, then, an import into a destination country, and as such, would be liable to tax in that country. If A (located in a high tax jurisdiction) 
acquires a license from $B$ (located in a tax haven) to use its IP, this would give rise to a tax liability in the high tax jurisdiction. But the tax paid on that import would be deductible as a cost for A. Just as above, these two elements would exactly balance out. An alternative arrangement, as with other imports by taxed businesses, would be simply to disregard the import and the payment for it. In any case, since there are no real tax consequences of the transaction, the incentive to locate intangible assets in a low tax country would disappear under the DBCFT.

Finally, note that the DBCFT puts considerably less pressure on the notion of corporate residence than does the existing system, though at the cost of introducing a different notion of nexus than exists in current tax treaties. The tax base is essentially domestic sales less domestic expenses. There is no requirement for corporate residence to identify either sales or expenses. Sales are taxed in the country of the consumer, irrespective of corporate residence. And expenses are allowed in the country in which they are incurred, also irrespective of corporate residence.

The DBCFT is not perfectly robust to avoidance and evasion. Indeed, certain forms of evasion commonly found in the VAT sphere, such as fraudulently disguising domestic sales as exports, can be expected. However, if adopted in all countries the DBCFT is robust to the most significant and widespread avoidance mechanisms including locating intangible assets in tax havens, transfer pricing abuse and shifting profit through the use of debt. Their elimination is a major strength of the DBCFT.

\section{c. Ease of Administration}

We examine issues of implementation in detail in Section IV below. Here we simply outline the main specific features that differentiate the DBCFT - since the DBCFT eliminates the need for swathes of complex legislation which burdens the current tax system and increases compliance costs on taxpayers and revenue authorities alike.

Under the R-based cash flow tax, since debt and equity are treated in a neutral fashion, there is also no need for complex rules that police the border between the two. Further, due to the immediate expensing of all asset purchases under a cash-flow tax no rules are required to distinguish between assets that are expensed and those that are capitalized. It follows that there is also no need for complex depreciation schedules or to keep track of individual assets and their bases. 
The destination basis also brings extensive simplifying benefits. It eliminates the need for some of the most significant, yet complex and lengthy, extant anti-avoidance rules. These include including exit taxes, transfer pricing, Controlled Foreign Company, thin capitalisation and anti-inversion rules. These rules require constant updating to meet new planning strategies and their application is notoriously costly and burdensome. Their elimination thus provides significant benefits of simplification to both governments and businesses.

On the other hand, the DBCFT does raise some significant administrative challenges which are new to corporation taxes, but well known in VAT. One is the need to distinguish between real and financial flows; this is addressed in Section III. Others include the challenges posed by negative liabilities and the need to levy a tax in the place of sale, a particularly difficult problem for services and digital products; these are addressed in Section IV.

\section{d. Fairness}

What ultimately matters for the fairness of any tax system, of course, is how it affects people; and corporations are not, in other than a legal sense, people. But how we tax corporations does have implications for the fairness with which the tax burden is shared, both within and across countries. This section looks at the DBCFT in this light, and at the particular question of the suitability, or not, of the DBCFT for developing countries.

Incidence of the DBCFT

The effective incidence of the DBCFT - who bears the burden of this tax - can be most easily understood by recalling from Section I.3 that the DBCFT is equivalent to a VAT plus a matching deduction for wages and salaries. The incidence of the DBCFT will thus be the same as that of a tax on domestic consumption net of a subsidy, at the same rate, to domestic wages or, equivalently, a tax on domestic consumption financed by resources other than wage and salary income. These resources will have three components. 
First, in transition they will include returns to previous investments. Second, on an ongoing basis and in present value terms, rents: the return on investments in excess of that needed to cover the normal return to capital. But the precise identity of who bears this element of the tax depends on the nature of the exchange rate or price adjustment, discussed earlier.

Third, in the context of a country with a fixed exchange rate, introducing a DBCFT would tend to push up prices and wages. So the tax would be borne by any domestic consumption financed from income or resources other than wages and salaries, including domestic residents holding shares in companies subject to the DBCFT. This could also include individuals (typically the more elderly) consuming from their wealth, earning a minimum wage or in receipt of government transfer payments, such as pensions. Neutralizing some of the possible adverse distributional effects may require indexing such payments, and any minimum wage, to consumer prices.

But by contrast, in a country with a flexible exchange rate, nominal domestic prices would be unaffected; their value would change relative to world prices through an appreciation of the exchange rate. In this case, we would expect only domestic residents owning firms subject to the DBCFT and those holding assets denominated in the foreign currency to bear any tax burden; ${ }^{36}$ those consuming from wage income would again be unaffected. Note, though, that there are other valuation effects of adopting the DBCFT (rather than simply raising the tax rate under the DBCFT, as in Table 2) that must be taken into account. In particular, a move to immediate expensing of domestic investment lowers the value of existing capital relative to new capital, and a shift away from taxing foreign source income may raise the value of offshore assets.

A tax on consumption not financed by labour earnings would be expected to fall on the affected consumers, except to the extent that these consumers respond to the imposition of the tax. In general, these consumers may seek to avoid a tax on their consumption from non-labour income by changing their behaviour. ${ }^{37}$ For the DBCFT, however, some of the channels of response normally associated with corporate taxation would be absent. In particular, because the cash-flow tax base excludes the

\footnotetext{
${ }^{36}$ Non-residents holding assets denominated in the currency of the DBCFT country, on the other hand, would receive a benefit. And of course changes in the exchange rates may have other effects through contracts or pricing specified in its currency.

${ }^{37}$ If their demand for consumption goods is inelastic, then standard incidence analysis would conclude that these consumers bear the entire tax burden.
} 
normal return to saving, there would be no incentive to save less; ${ }^{38}$ and, because of the destination basis used for the cash-flow tax base, there would be no incentive for capital or business activity to move to other jurisdictions, as already discussed.

One possible shift away from taxation that remains under the DBCFT would be through cross-border shopping, if other nearby or accessible jurisdictions impose tax at a zero or lower rate. ${ }^{39}$ With few exceptions, however, significant cross-border shopping has tended to be confined to excisable goods: in response to general differences in rates of VAT, in particular, it has tended to be modest. (The treatment of remote purchases is discussed later). If demand is reduced, we would expect some of the tax to be borne on the supply side, for example by factors entering the production process, regardless of their location, such as the intangible assets a company owns. ${ }^{40}$

This analysis indicates an important point regarding the incidence of the DBCFT: it would likely be considerably more progressive than a broad-based VAT, which falls on the generality of consumers. ${ }^{41}$ The comparison with a conventional corporate tax is more complex. On this it is important to remember that the latter is at least to some extent passed on in higher prices to consumers and in lower wages to workers. Replacing a conventional corporate tax by the DBCFT would remove the normal return to capital from tax ${ }^{42}$ Though we do not discuss here the issues that this raises, a tax on the normal return to capital could, if so desired, be levied at personal level. ${ }^{43}$

\footnotetext{
${ }^{38}$ Unless of course such a tax was levied at personal level.

${ }^{39}$ This depends on how the place of the sale is defined. In principle, we are searching for the least mobile tax base - which is probably the normal place of residence of the consumer, rather than the place of purchase. This would imply that a consumer that shops abroad would still be taxed at her domestic tax rate. But in practice this is unlikely to be feasible, certainly in all circumstances. See the discussion in Devereux and de la Feria (2014).

${ }^{40}$ An alternative approach to understanding the incidence of the DBCFT is to start with an origin-based cash-flow tax, which would impose a tax on the cash flows of firms' domestic operations. In general, such a tax would fall on the owners of the business. The border adjustment included in the DBCFT would in effect convert the tax base from a tax on the cash flows received by owners of domestic firms to a tax on the cash flows received by domestic owners of firms worldwide. See Auerbach and Devereux (2015).

${ }^{41}$ VATs in practice of course often include reduced rates on some items precisely in order to improve their progressivity. As is widely recognized, however, this is an extremely inefficient way in which to pursue distributional objectives, especially in advanced economies that have quite finely targeted income support measures available to them. The implication is that distributional impact can be improved by moving to a single rate VAT while strengthening income support (Crawford and others (2010)).

42 The same would be true of any form of rent taxation.

${ }^{43}$ This is the approach, for instance, of the Business Enterprise Income Tax proposed by Kleinbard (2007), which combines a rent tax at corporate level with a tax on the normal return at the personal level.
} 
Taxing sales on a destination basis but giving relief for expenses on a source basis can produce an allocation of profits amongst states which might be considered to be inequitable. If a company produces goods in country $A$ and exports to country $B$, then, under a DBCFT, A would not receive any tax on the company's profits. A system under which a government which potentially contributes significantly to the success of business operations by providing infrastructure, legal protection and other goods and services, but receives no tax revenue - while governments that contributed nothing happily pick up a cheque - might be considered to be unfair, or at least inappropriate, violating a view of taxation as in part payment for the benefits provided by governments.

Note, however, that current taxes on business profit do not satisfy the prescriptions of the benefit principle either, as they can result in high taxation for companies which derive very little value from publicly provided goods and services and no taxation for companies which derive a great value. In other words, there is no necessary connection between benefits derived and taxes paid. Concern for the benefit principle would thus be better addressed through the adoption of fees based on a businesses' footprint in a particular state. Such fees could be introduced alongside a DBCFT by states so wishing to do, although, of course, this could affect the attractiveness of the country as a location for investment.

Furthermore, this issue should be viewed at a state rather than at an individual company level. Under a DBCFT there will certainly be instances in which little or no tax is collected by states from businesses which export a high percentage of their products or services. However, such states will also tax the profits of businesses which incurred their production costs in a different jurisdiction. Viewed at a state level, then zero-rating of exports and taxation of imports would net out in the aggregate tax base to the extent that there was a balance of trade, with exports equal to imports. Of course, net exporting states would find themselves on the wrong side of this balance. However, two factors militate against the conclusion that the DBCFT would not be right for such countries. First, net trade positions change over time, albeit extremely slowly in some cases, and net exporting states might find themselves closer to a balance of trade or even net importers in years to come. Second, states which seek to tax on a source basis because of the benefit principle might in time find themselves 
simply unable to do so. Competitive forces will continue driving down corporate tax rates under the current system and businesses will respond by moving their real activity.

More generally, apart from the shift to a destination basis, there would be several effects on the revenue generated from the DBCFT, relative to the revenue generated from the conventional tax. First, as noted above, the DBCFT should make it considerably harder to shift profits to low tax jurisdiction. Second, the pressure to have a low rate of tax in order to compete with neighbouring countries disappears when all adopt a DBCFT, since, as seen above, location decisions by business should be independent of the rates at which each levies its DBCFT. Each country could therefore raise its tax rate without fearing an exodus of either real economic activity or taxable profit. On the other hand, moving to a cash flow tax might reduce the tax base relative to a conventional tax, since the cash flow tax provides immediate expensing rather than traditional depreciation deductions; in the other direction, the conventional tax allows interest payments to be deducted, while the DBCFT would not. The net impact of these two offsetting effects on the tax base is unclear, and would depend on the initial circumstances in a particular country with respect to the generosity of existing depreciation schedules and the extent of leverage in corporate capital structure. While one cannot say for certain that these offsetting changes in the tax base, combined with less profit shifting, would lead to an overall broadening of the tax base, the opportunity to increase the tax rate without concern about crossborder shifting at least offers the possibility of recovering any revenue lost if these effects reduce the tax base. ${ }^{44}$

Distinct considerations may well apply to natural resources. These are often largely exported, a major source of government revenue, and perceived as a national asset. Governments of resource-rich countries are unlikely to be content to receive, as they would under a DBCFT, no revenue from their exploitation - and even finding

\footnotetext{
${ }^{44}$ Patel and McClelland (2017) examine some of the revenue consequences of introducing a DBCFT in the US, on the assumption of unchanged behaviour of businesses. They find that, over the period 200413 , if the US had an origin-based cash low tax in place, the total tax base would have been almost the same as under the actual tax system in place at the time. Also the number of firms with tax losses, both unweighted and weighted by assets, would have been almost identical to the actual tax system. Because the US had a trade deficit during this period, moving from this to a destination-based cash flow tax would have significantly increased the aggregate US tax base. The proportion of firms with tax losses would again have been barely unchanged on an unweighted basis, but would have been higher weighted by assets, reflecting the fact that firms that participate in cross-border transactions tend to be larger.
} 
themselves paying large amounts to foreign extractive firms. Moreover, while the DBCFT looks to the immobility of consumers, this is a case in which there is an immobility of the underlying asset - giving rise to rents that are specific to their location - that can be exploited. There are thus powerful forces pointing to the retention of some element of origin-based taxation of natural resources as both a political reality and a potentially efficient form of taxation. ${ }^{45}$

\section{Developing countries}

Business tax reform is a high stakes game for developing countries - perhaps even more so than for advanced countries. They are in many cases heavily reliant on tax revenues from the extractive industries, derive a larger proportion of their total revenue from non-resource corporate taxes than do higher income countries, and have fewer realistic alternative sources of revenue. All this makes it important to consider the case for movement towards a DBCFT especially closely for them. There are four main issues.

The first is the treatment of natural resources. As argued above, there is a strong case to retain origin-based taxes on these. Thus the impact of the DBCFT on developing countries should thus be considered once revenue from natural resources is carved out.

The second is the impact on the tax base. Broadly, moving from a traditional sourcebased corporate tax to a DBCFT means - assuming no change in behaviour - losing revenue to the extent that exports exceed imports, and to the extent that the sourcebased tax is levied on the normal return to capital. ${ }^{46}$ The likely extent of the latter, however, is hard to assess. While one could argue that this could in any event be recouped, at least in relation to domestic owners, by levying the tax at a personal level, experience on the taxation of capital income in low income countries is not encouraging.

\footnotetext{
45 Efficiency would call for some form of resource rent taxation, though administrative considerations may imply balancing this with royalties (charges on the volume or, more commonly, the value of output) which, though more distortionary, may be less vulnerable to avoidance through the manipulation of costs: see Boadway and Keen (2010). Similar considerations would apply to other cases in which there are location specific rents that derive largely from exportation.

${ }^{46}$ There could also be some loss from the removal of withholding taxes on payments to nonresidents, to the extent that these are not already undermined by treaty shopping.
} 
To consider the likely direction of effect through the trade balance, suppose a country currently has both a tax on natural resources and a conventional corporation tax, which applies both to natural resources and all other activities. Now suppose that the country continues to tax its natural resources at the same level - including both existing sources of taxation. But for non-resources, it border adjusts its corporate tax. Then, in aggregate, and abstracting from other factors affecting the tax base, the country would see a rise in its taxable income if all imports exceeded exports from the non-resource sector. We are able to analyse the position of a large number of countries using data on balance of payments statistics from UNCTAD, with information on exports of natural resources from UNComtrade. We can identify 17 countries out of 181 analysed for whom, over the period 1996-2014, exports excluding natural resources exceeded imports. These include Japan, China, Germany, Switzerland and Sweden. Only one low income country (Nepal) and four lower middle income countries (East Timor, Uzbekistan, Bangladesh and Philippines) are included in this list. If these countries continued to have such an imbalance of trade then moving to a destination basis would tend to reduce their corporate tax base. But the overall effect on their revenue would also be affected by the other factors described above. However, for all other countries, if they maintained similar taxes on their natural resources, then these calculations suggest that moving to a DBCFT for non-resource trade would tend to increase their tax base.

A third consideration that is common to all countries but applies with particular force to many developing countries is non-compliance. The existence of an untaxed sector means that the equivalence results set out earlier clearly do not apply - so these may be further off the mark for developing than for advanced countries. More to the immediate point, if (as seems plausible) the untaxed sector viewed on its own tends to have a trade deficit - importing more than it exports - then the view of the likely revenue impact set out in the previous paragraph will be over-optimistic. There is cause for more optimism, perhaps, on the impact of movement towards the DBCFT on compliance: all else equal, remission of the tax on the normal return would make entrance into the corporate tax more attractive, while the wage deduction should also make the DBCFT more attractive to comply with than the VAT.

A fourth consideration is the greater weakness of tax administrations in developing countries. Here the heightened need to refund losses is a major concern. This remains a major issue under the VAT, and - in whichever form adopted - would be amplified 
under a DBCFT or the equivalent VAT cum payroll subsidy. Cross-crediting is more difficult in such countries, both because of the administrative challenges this implies and because there are fewer taxes against which credit might be taken: there are commonly no payroll contributions and only modest personal income taxes. Corruption and fraud are obvious concerns in the processing of refund claims (indeed credits more generally). But the greater difficulty with VAT refunds has commonly been not too many, but too few, as administrations either adopt strong safeguards or lack access to the funds to pay them.

Against all this, however, one must weigh the weaknesses of current international tax arrangements. These, in many respects, have not served developing countries well: the evidence is that, relative to their total revenues, they lose more from BEPS-type avoidance than do advanced economies. ${ }^{47}$ And they are exposed too to the rigours of aggressive international tax competition. The gains from escaping those (except in relation to natural resources) could, over the long haul, outweigh quite considerable shorter-term difficulties.

\section{e. Stability}

The existing tax system for taxing profit and alternatives such as a residence-based tax on the parent company and a multi-factor formulary apportionment system are or would be destabilized by competitive forces which drive countries to cut their tax rates. We have seen, however, that the DBCFT would not be subject to competitive forces of this kind, since reducing the tax rate of a DBCFT would not help attract inward investment, headquartering or business activity, nor would it be necessary to combat tax avoidance. States can thus set their DBCFT rates in accordance with their own preferences, without concern about the rates set by other states. By neutralizing these competitive forces, the DBCFT would provide long term stability in the tax system; this is one of its principle merits.

\section{Unilateral adoption}

So far we have considered the properties of the DBCFT if it were introduced in all countries, possibly at different rates. But of course, it is very unlikely to be introduced

\footnotetext{
${ }^{47}$ See, for example, Crivelli and others (2016).
} 
by general agreement in many countries. An important issue is therefore what the properties of the DBCFT would be if it were introduced in only one country, or a small group of countries. For considerations of stability, we are interested both in the effects on countries which introduce it, and on those that do not. In particular, we are interested in the incentives of the first group as to whether to continue to use a DBCFT, and in the spillover effects on those that do not, including their incentive to respond by adopting a similar system - and including, for both, the implications for likely extent and nature of tax competition. We address the same five criteria as in the previous section.

\section{a. Economic efficiency}

A DBCFT adopted unilaterally by one country would have the same efficiency properties in terms of scale of investment in that country, as a DBCFT adopted universally. For the case of purely domestic activity, or equivalently, for an origin based cash flow tax, this is demonstrated by the example in Table 1. Adding border adjustments where some of the cash flows associated with the investment represent either imports or exports does not affect this neutrality property. Consider for example, the case in which a domestic firm exports, and thus does not pay tax on its sales. In this case, the exchange rate appreciation arising from the introduction of the border adjustment offset the benefit of the zero-rating of exports. This leaves the scale of any investment decision in the country unaffected by the domestic DBCFT (although it might in principle be affected by taxes levied on the export by the importing country). The DBCFT is also neutral with respect to borrowing from domestic sources, as we discuss in detail below. We discuss the incentive to shift borrowing among countries to the section on the taxation of financial flows below.

However, location of investment decisions would be distorted. Suppose country A used a DBCFT but other countries maintained an origin-based corporation tax. Then, in effect, $A$ would not levy tax on the returns to economic activity taking place in A apart from economic activity in the form of sales. This clearly would create an incentive for companies to locate economic activities such as manufacturing in $A$, no matter how low the origin-based tax in country B. Note however, that the advantage of locating such activity in a DBCFT jurisdiction would not vary with the rate at which it is charged. This is because, as we argued above, relief for costs incurred on that economic activity would be offset by a rise in relative prices, so the net impact of the 
DBCFT would be tantamount to reducing its origin-based tax on corporate income to zero. And this would be true whatever the tax rate in the DBCFT jurisdiction.

In effect, replacing an origin-based tax on profit with a DBCFT could be seen as an aggressive move in the existing tax competition game. Origin-based taxes on corporate income would continue in other countries, giving companies an incentive to locate, or relocate, their activities to country $A$. This would be true irrespective of the market in which the product was destined to be sold.

\section{b. Robustness to avoidance and evasion}

The unilateral adoption of a DBCFT would leave existing avoidance opportunities in place; however, they would operate to the detriment of the rest of the world, not that of the adopting country. Consider, for example, incentives for transfer mispricing. In the previous section, we argued that if two countries adopt the DBCFT, a company could not shift profits from one to the other by mispricing intra-group transactions. But what would happen if country A adopted a DBCFT, but country B maintained the existing source-tax based tax?

As we have seen above, cross-border intra-group transactions would not appear in the tax base in country A. Exports would be excluded from the tax base. Imports could be treated in two ways: they could be taxed, but with this tax then exactly netting against the relief for the cost of the input; or they could be just ignored. In either case there would be no tax consequences in country A. But the declared prices used for intra-group cross-border transactions would still affect the tax base in country $B$. If the company was exporting from $B$, there would be an incentive to under-price the export. If the company was importing to $B$, there would be an incentive to overprice the import. This incentive arises independently of the tax rates in $A$ and $B$.

A similar analysis applies to the strategic location of intangible assets. Under the existing system, there is an incentive for companies to locate intangible assets in lowtax countries and pay royalties and license fees from high-tax countries to where the assets are owned. But, as we argued above, this incentive would not be present in a country with a DBCFT, however high the rate. That is because the use in the DBCFT country of the benefits of the intangible asset would be treated as an import. The tax on the import would again net out with tax relief on the purchase of that import; or 
the import could be ignored entirely. In either case, there is no net deduction for the cost of using the imported service from the intangible asset.

If other countries maintained existing source-based systems, however, then there would be an incentive to locate intangible assets in the DBCFT country, since there would be no tax on the receipt of royalty or license fees. To this extent, the DBCFT country would again be operating in a way akin to a tax haven under a source-based tax system. Royalty payments to the DBCFT country would generally be deductible in other countries; this would facilitate a reduction in taxable income in those countries, although it would not be shifting the tax base to the DBCFT country, since the income would not be taxed there.

As will be seen later, the preferred treatment of financial flows under a DBCFT can also worsen base erosion in non-adopters, since interest payments may be deducted in the non-adopting countries but untaxed in the DBCFT country.

The adoption of the DBCFT by a single country is thus very likely to aggravate the problems of base erosion and profit shifting in countries that did not implement a DBCFT, whilst rendering the adopter immune from such activity - indeed turning it into a beneficiary. This is, or should be, a significant concern with unilateral adoption. The quantitative impact of additional profit shifting opportunities on other countries will be hard to gauge: multinationals already have many opportunities to shift profits to low rate jurisdictions. And the impact will depend on the particular circumstances, being greater, for instance, if the adopter is a large and initially high-tax country.

The likelihood is, in any case, of increased pressure on the devices that non-adopters have at their disposal to limit profit-shifting: thin capitalization rules, withholding taxes and the like. While the most direct responses are in the hands of the nonadopters, the adopter may also wish to protect foreign tax bases from undermining through artificial transactions and pricing. Participation in the county by country reporting that is a minimum standard under the G20-OECD BEPS project, for instance, may yield little direct benefit to the adopter, but can be helpful for others in addressing transfer pricing issues. Even if adequate responses can be shaped, however, this - or, as discussed below, following suit by adopting a DBCFT - is likely to take some time, during which the adverse impact on non-adopters might be significant. 


\section{c. Ease of Administration}

For the country adopting it, the main administrative benefits and costs of adopting a DBCFT - prominent among the former being that opportunities for shifting profit to low taxed jurisdictions are at least considerably diminished, if not extinguished - are much the same whether adopted unilaterally or universally.

Two issues would arise if the DBCFT were introduced unilaterally, however. First, as we discuss in detail in Section IV on implementation below, there would be benefits in tax collection if countries cooperated with each other. These benefits would presumably be much less likely to occur if a country introduced the DBCFT unilaterally. Second, from the perspective of taxpaying multinationals, there may be an additional compliance cost in dealing with a DBCFT in one country, and existing corporation taxes in other countries, although of course businesses must already cope with quite significant differences in national tax systems.

\section{d. Fairness}

Broadly, the considerations of fairness are the same as if the tax were introduced globally. The tax would continue to be equivalent to a tax on domestic consumption financed by resources other than wage and salary income. The issues of inter-nation equity are also similar as well, though with the additional twist of the likely impact of increased profit shifting out of non-adopters.

The factors influencing revenue (other than BEPS-type through avoidance) would again be similar. However, in the case of unilateral adoption of the DBCFT, the behavioural response of multinationals would be different, and this could affect revenue, and welfare of the country that introduced the tax. For example, suppose that country $A$ introduced a DBCFT and country B did not. Then a company that produced in $A$ and exported to $B$ would face no tax on its profit. But a company that produced in $B$ and sold in $A$ would be taxed on its profit in $B$, and on its import to $A$. This might be considered unfair, but is simply the result of the two countries having a different basis for taxation. 


\section{e. Stability}

The attractiveness of moving from a traditional source-based corporate tax from the perspective of a single country, acting on its own, involves a trade-off, as discussed in Auerbach and Devereux (2015), between the benefits of attracting capital and profits from other jurisdictions and the potential costs of a reduced ability to "export" taxes to the residents of other countries. A country unilaterally introducing a DBCFT would in effect be reducing its source based tax on corporate income to zero. As discussed, this would attract real activity and profit from other countries where that sourcebased income would be liable to tax. But on the other hand, a source-based cash flow tax would fall in part on the owners of the business being taxed, including nonresident owners. By contrast, as discussed above, a destination-based tax would ultimately fall only on domestic residents. A move to a DBCFT from a source-based cash flow tax would therefore have a cost in reducing the ability of the country to levy a tax the incidence of which is partly on non-residents. This second factor may be more important for a large country, or one with unique location-specific production assets (as in the case of natural resources, discussed earlier), and so countries in such circumstances may find adoption of a DBCFT less attractive.

However, existing corporate taxes are less likely to be "exported" to non-residents than source-based cash flow taxes. That is because existing taxes do not generally fall solely on economic rent; consequently, they create incentives for companies to distort their behaviour and prices in ways that pass on the burden of the tax to others, particularly residents. This, while there is a clear trade-off between source and destination-based cash flow taxes, the benefit of a conventional source-based tax in exporting tax to non-residents is weaker than with a source-based cash flow tax.

In addition to effecting a zero tax rate on domestic source income, the treatment of borrowing and interest under the DBCFT would introduce a powerful incentive for adoption elsewhere, for it would shift borrowing and interest deductions to other jurisdictions where interest is still deductible (at least as long as the other jurisdictions did not combat this incentive by the use of anti-avoidance rules). Similarly, as the adoption of the DBCFT by one state safeguards it against a number of profit shifting techniques, whilst providing opportunities for MNEs to shift profits from states operating a source based corporation tax to it, it gives these states an incentive to adopt the DBCFT too. 
For non-adopters, as seen above, despite such possible defences as mentioned there - and to an extent that again depends on circumstances - the replacement of a traditional corporate income tax by a DBCFT in another country may, depending on circumstances, place substantial pressures in the forms of both reduced investment and heightened profit shifting. They are likely to respond. This may take the form of either reduced statutory rates or base narrowing measures, while retaining a traditional CIT, or a mimicking movement to a DBCFT. The former response provides no lasting solution to continued tax competition. Subject to important caveats notably those in relation to developing countries discussed above - the latter may well have more attractions than the continued undermining of the international tax systems that is all too clear under current arrangements.

How the incentives for adoption would change in response to other countries' adoption is a complex question. Empirical evidence - see, for example, Devereux et al (2008) - suggests that countries respond to a reduction in the tax rate in other countries by reducing their own tax rate. That in turn suggests that the attractiveness of adopting the DBCFT would be enhanced by other countries already having done so. That is because countries that kept a source-based tax would be at a competitive disadvantage since in effect they would be competing for real economic activity and profit with countries that have no source-based taxation. As investment and profits shifted to the countries that had unilaterally introduced the DBCFT, there would be a powerful incentive for other countries to follow suit. The unilateral introduction of a DBCFT could therefore be seen as an aggressive move in the tax competition being played out in source country corporate taxes. This would seem to be further enhanced by the treatment of interest under the DBCFT, as one would expect borrowing to shift from countries as they adopt the reform to countries that have yet to do so.

A unilateral move to the DBCFT can be seen as the ultimate move in a tax competitive game, as it results in a source based corporation tax rate of zero. However, the adopting state would not be susceptible to tax competitive forces on the tax rate it selects. In that sense the acceleration of one tax competitive game also puts a stop to another and would provide long term stability for the adopting state free from destabilizing tax competitive forces. 


\section{TAXING FINANCIAL FLOWS}

The growing importance of financial institutions and activities within the corporate sector (see the statistics for the UK and the US in Auerbach et al, 2010) increases the attractiveness of taxing the economic rent accruing to financial companies. This section considers how this can be achieved, first under a DBCFT and then under a VAT-based equivalent.

\section{The choice between an $R$ base and an $R+F$ base}

As discussed earlier, there are two basic approaches to the treatment of financial flows under a cash flow tax, including the DBCFT. These were set out by the Meade Committee (1978), and we use their terminology here. The first option is simply to ignore them, and that - in the sense of exempting or 'input-taxing' them ${ }^{48}$ - is the route taken by most VATs. This is equivalent to a tax only on "real" inflows, which Meade calls the R-base. The second is to tax also all net financial inflows other than equity transactions with its shareholders, which Meade calls the $R+F$ base. Table 4 , which is adapted from Meade (1978), shows which flows that would be subject to tax under an $\mathrm{R}$ and an $\mathrm{R}+\mathrm{F}$ base.

Table 4. Elements of $R$ and $R+F$ base taxation

\begin{tabular}{|l|l|}
\hline INFLOWS & OUTFLOWS \\
\hline R1 Sales of goods & $R^{*} 1$ Purchases of materials \\
$R 2$ Sales of services & $R^{*} 2$ Wages and salaries \\
$R 3$ Sales of assets & $R^{*} 3$ Purchase of fixed assets \\
\hline$R$ & $R^{*}$ \\
\hline & Feal Items \\
F1 Increase in any forms of borrowing & $F^{*} 1$ Decrease in any form of borrowing \\
F2 Decrease in any form of lending & $F^{*} 2$ Increase in any form of lending \\
$F 3$ Decrease in cash & $F^{*} 3$ Increase in cash \\
F4 Interest received & $F^{*} 4$ Interest paid \\
F5 Decrease in holding of shares in foreign & $F^{*} 5$ Increase in holding of shares in \\
companies & foreign companies \\
\hline$F$ & $F^{*}$ \\
\hline
\end{tabular}

${ }^{48}$ This means that no tax is charged on sales, but tax charged on purchases cannot be recovered. 
In the table, "real" inflows are denoted as $R$ and "real" outflows are denoted as $R^{*}$. The $\mathrm{R}$ base is therefore simply net real inflows, $R-R^{*}$. The key elements of each flow are shown in the table.

The "financial" element is also straightforward, although perhaps less intuitive. The "financial" tax base would be inflows, $F$ - including new borrowing, interest received and reductions in cash holdings - less outflows, $F^{*}$ - including repayment of borrowing, interest payments and new lending. The " $\mathrm{R}+\mathrm{F}$ " base would include both real and financial flows, that is, in the notation of the table, would be $R+F-R^{*}-F^{*}$.

Note that, at least in a domestic setting as noted by the Meade Committee, an R+F base is equal to net distributions to shareholders - that is, distributions from the company to shareholders net of new equity issues. Thus, a tax on the R+F base could be implemented alternatively as a tax on distributions to shareholders net of new equity issues (the 'S base', in Meade's terminology). This could in principle be imposed at either the company level or the shareholder level, the latter opening up the thought of rooting cash flow taxation in the residence of the shareholder, rather than the location of consumption. ${ }^{49}$ We consider the $\mathrm{S}$ base no further here.

Now compare tax liabilities under the $R$ and $R+F$ bases. We focus here initially on the interaction between the financial and nonfinancial sectors, starting with the domestic case so as to leave aside for the moment the issue of the location of tax.

\section{Transactions between taxable entities}

Consider first the application of the $\mathrm{R}+\mathrm{F}$ base to both sectors. When a bank lends to a nonfinancial company, the outflow of funds receives tax relief in the hands of the bank. But the company is taxed on its financial inflow. As long as the lender and borrower face the same tax rate, the net tax on the transaction is zero. The same applies when the company repays the bank with interest. The repayment of principal and interest by the company reduces the company's taxable income, but the receipts to the bank are taxed. Again, if the tax rates are the same, then the net tax is zero.

\footnotetext{
${ }^{49}$ A possibility stressed for instance by Cui (2015).
} 
Table 5 demonstrates this. In this example the bank lends 100 to a nonfinancial company at a $10 \%$ interest rate. The corporate tax rate is $30 \%$. Taking only these financial flows into account, the taxes on the borrower and lender net out in each period, with the result that no net tax is paid.

Table 5. Treatment of Financial Flows under the $R+F$ base

\begin{tabular}{|l|c|c|c|c|c|}
\hline & \multicolumn{2}{|c|}{ Pre-tax flows } & \multicolumn{3}{c|}{ Tax flows } \\
\hline & Bank & Borrower & Bank & Borrower & Total \\
\hline Period 1: Lending & -100 & +100 & -30 & +30 & 0 \\
\hline $\begin{array}{l}\text { Period 2: Repayment } \\
\text { with interest }\end{array}$ & +110 & -110 & +33 & -33 & 0 \\
\hline
\end{tabular}

An equivalent system would be one in which the financial flows between the financial and nonfinancial sectors are ignored for the purposes of tax. But this is exactly what the R-base does. So in effect there is no economic difference between the $\mathrm{R}$ base and the $R+F$ base with respect to financial flows between entities that are liable to the same tax system.

However, to compare the $\mathrm{R}$ and $\mathrm{R}+\mathrm{F}$ base in more detail, we will expand the example, as shown in Tables 6 and 7. Now suppose that the bank receives deposits of 100 from an individual or other tax exempt entity, on which it pays interest of $5 \%$. It lends the 100 to the company at a rate of $10 \%$. The bank therefore makes a pre-tax profit of 5 . The company invests 100 , financed by borrowing, and earns a return of $20 \%$, so that it has a value of 120 in period 2. It repays 110 to the bank and therefore earns a pre-tax profit of 10 . Given that there are no other costs, these measures of pre-tax profit are actually economic rent. The total rent is therefore 15 , with the company earning 10 , and the bank earning 5 .

The position under the $\mathrm{R}+\mathrm{F}$ base is as shown in Table 6. All real and financial flows are taxed. In period 1, all flows net to zero. The bank borrows and lends 100 , with no net tax consequence. The company borrows 100 and invests 100 also with no net tax consequence: the tax due on its receipt of the loan is exactly matched by the value of the deduction for its investment. 
Table 6. Treatment of Financial Flows under the $R+F$ base

\begin{tabular}{|l|c|c|c|c|}
\hline & \multicolumn{2}{|c|}{ Pre-tax flows } & \multicolumn{2}{c|}{ Tax Flows } \\
\hline & Bank & Borrower & Bank & Borrower \\
\hline Period 1 & & & & \\
\hline Bank receives deposit & 100 & & 30 & \\
\hline Bank lends & -100 & 100 & -30 & 30 \\
\hline Investment by borrower & & -100 & & -30 \\
\hline Total period 1 flows & 0 & 0 & 0 & 0 \\
\hline Period 2 & & & & 36 \\
\hline Return earned by borrower & & 120 & & -33 \\
\hline Repayment with interest & 110 & -110 & 33 & \\
\hline Repayment to depositor & -105 & & -31.5 & 3 \\
\hline Total period 2 flows & 5 & 10 & 1.5 & \\
\hline
\end{tabular}

In period 2, the company pays tax on the value of its investment, but gets tax relief on what it repays to the bank. The bank pays tax on its receipts from its lending, but gets tax relief on its repayment to its depositors. In sum, the bank pays tax of 1.5 and the company pays tax of 3 . In both cases, this represents $30 \%$ of the pre-tax economic rent earned by each party.

Now consider the $\mathrm{R}$ base, as shown in Table 7. In this case, financial flows are simply disregarded. Let us start by assuming that the company still wants to make its investment of 100 . It receives tax relief on that investment of 30 . Consequently, it need only borrow 70 from the bank. Since no taxes are levied on the financial flows of the bank, the bank only has to raise 70 from its depositors. In period 2, the company earns 120 and pays tax on that of 36 . It repays 77 to the bank, including $10 \%$ interest, and the bank repays 73.5 to the depositors, including 5\% interest. There are no other taxes.

There are clearly differences in cash flows in these two examples. The bank only borrows and lends 70 . And the company receives tax relief of 30 in period 1 , and pays tax of 36 in period 2. But exactly the same real investment is undertaken, and both the bank and the company are exactly as well off as they were under the $\mathrm{R}+\mathrm{F}$ base. The bank has a post-tax rent of 3.5, and the company has a post-tax rent of 7 (4336). Further, if we gross up the 30 of tax relief from period 1 at the "normal" (deposit) 
interest rate of $5 \%$, this is equivalent to tax relief of 31.5 in period 2 . The overall tax liability in period 2 terms is then 4.5 , exactly as under the $\mathrm{R}+\mathrm{F}$ base. ${ }^{50}$

Table 7. Treatment of Financial Flows under the $\mathbf{R}$ base

\begin{tabular}{|l|c|c|c|c|}
\hline & \multicolumn{2}{|c|}{ Pre-tax flows } & \multicolumn{2}{c|}{ Tax Flows } \\
\hline & Bank & Borrower & Bank & Borrower \\
\hline Period 1 & & & & \\
\hline Bank receives deposit & 70 & & & \\
\hline Bank lends & -70 & 70 & & \\
\hline Investment by borrower & & -100 & & -30 \\
\hline Total period 1 flows & 0 & -30 & 0 & -30 \\
\hline Period 2 & & & & 36 \\
\hline Return earned by borrower & & 120 & & \\
\hline Repayment with interest & 77 & -77 & & 36 \\
\hline Repayment to depositor & -73.5 & & & \\
\hline Total period 2 flows & 3.5 & 43 & 0 & \\
\hline
\end{tabular}

If under the $\mathrm{R}$ base the bank is not being taxed on its return from lending, then it may appear that it can earn an economic rent without tax. But in this case, any economic rent it earns is effectively being taxed in the hands of the borrower. Under the $R+F$ base, the company and the bank each pay tax on their share of the overall economic rent earned. Under the $\mathrm{R}$ base the company would get no tax relief for repaying its debt with interest. In effect it is therefore taxed on the entire economic rent, while the bank is not taxed at all. Thus, the netting procedure under the $\mathrm{R}$ base effectively transfers part of the tax base from financial firms to nonfinancial firms.

But, as the example makes clear, this does not mean that the bank gains at the expense of the company. This is because the amount of lending is lower under the $R$ base. At the same interest rate, then, the bank earns a lower pre-tax economic rent.

\footnotetext{
${ }^{50}$ Note that this equivalence depends on grossing up the tax relief in period 1 by $5 \%$ to transform it into a period 2 value. This is based on the deposit rate paid by the bank in the previous example. Note though, that if the discount rate were $6 \%$, but the bank earned rent on its borrowing by paying only $5 \%$ to its depositors, then the overall tax liability in period 2 terms would be lower than under the $\mathrm{R}+\mathrm{F}$ base. In effect, the rent earned by the bank on its borrowing would be untaxed, illustrating the need in general to include financial transactions with non-taxable entities and individuals in the tax base, as described below.
} 
We noted above that a main weakness of the $R$ base is thought to be its inability to tax economic rents earned by the financial sector. However, these examples show that this is not true in the case of lending and borrowing between two businesses subject to the $\mathrm{R}$ based tax.

Four other important issues arise in comparing the $\mathrm{R}$ and $\mathrm{R}+\mathrm{F}$ bases for transactions between entities liable to the tax.

The first concerns any other expenses incurred by the bank. Suppose in our example, the bank has additional costs of 5 in period 2 - say employment costs. Under the R+F base analysis, this would extinguish the bank's economic rent; in effect the bank would not earn a rent. That would be dealt with easily by the $R+F$ base: the additional 5 of costs would be set against net income of 5 in period 2, and the bank's R+F tax liability would fall to zero. The total tax paid would then be only the 3 paid by the bank on its economic rent of 10 .

Under the R base, however, the bank has no taxable income, since all of its income is in the form of financial flows. Yet the $R$ base would still give tax relief for this additional real cost. In effect, the bank's $R$ base taxable income should be negative, at -5 , and under a symmetric tax system, it should receive a tax credit of 1.5 . Give that the value in period 2 terms of the tax paid by the company is 4.5 , then that tax credit is required to make the $R$ and $R+F$ bases comparable in this case. The taxable loss arises for the bank under the $\mathrm{R}$ base because its taxable income has in effect been transferred to the company, as explained above. It is true that there may be a problem of perception, as people may find it difficult to understand why banks should apparently be subsidized despite the fact that they may be earning economic rent. ${ }^{51}$ But this is indeed a problem only of perception, since, as set out here, the underlying economic rent is being taxed in the hands of the borrower.

That raises issues of how a credit would be paid, and in what circumstances. The bank has not made a loss, yet under the $\mathrm{R}$ base it may have a negative tax base. Dealing with the tax loss by carrying it forwards, even with interest, would be inadequate as financial firms with underlying profitability could easily be in permanent tax loss positions. One option would be simply to give a tax rebate to the bank. A second

\footnotetext{
${ }^{51}$ This problem of perception may arise even if the bank appears to be paying low or no tax under the R base.
} 
would be to allow the bank to offset the negative taxable profit against its liabilities for other taxes.

A second issue which arises under the $R+F$ base is that companies are able to defer their tax payment, possibly indefinitely, through the simple expedient of not paying the profit to their shareholders. For example, consider the borrower in the example above. Under the $\mathrm{R}+\mathrm{F}$ base it has a pre-tax profit in period 2 of 10 , which is implicitly assumed to be paid as a dividend to its shareholders. But suppose instead that it simply saved the money in a financial account: either cash in a bank, or buying government bonds, for example. Either form of such saving would be treated as a financial outflow (of the form $\mathrm{F}^{*} 2$ or $\mathrm{F}^{*} 3$ in the table above) and would therefore reduce the $\mathrm{R}+\mathrm{F}$ base of the company to zero.

One possible response to this is that this is not a problem. The $R+F$ base is in effect a tax on net distributions to shareholders. So if no net distribution is made, then there is no tax. If the company buys bonds in one period, for example, and earns interest on those bonds, then the dividend paid in the following period would be higher by the amount of the interest, and hence the tax liability at that point would also be higher. If the interest rate earned is the same as the shareholder's discount rate, then the net present value of the post-tax return to the shareholder would be unaffected.

However, this argument does not take account of the fact that there could be advantages in deferring tax from the perspective of financial reporting. As noted in Section I, company directors may be evaluated on the basis of the profit declared in their financial statement; this is particularly true for listed companies. If the deferred tax is not included in the profit and loss statement (which may happen if the deferral is expected to be for a long enough period) then the reported post-tax profit would be boosted. Such an incentive to keep cash within the business may reinforce agency problems as directors seek to avoid the discipline of raising finance from the debt markets, potentially giving rise to corporate over-investment. The susceptibility of the $\mathrm{R}+\mathrm{F}$ base to the timing of tax payments provides a strong reason to prefer the $\mathrm{R}$ base, at least for transactions between financial and non-financial companies that face the same tax system and tax rate. ${ }^{52}$

\footnotetext{
${ }^{52}$ The problem remains to some extent if, as discussed below, financial transactions with tax exempt entities and individuals are taxed. Then in principle, tax could be deferred by lending to these groups. If this problem were serious enough, it might in practice be counteracted by requiring there to be a deemed dividend in place of the additional lending.
} 
A third issue is that banks may charge their borrowers in ways other than through interest - for example, through fees. Under an $\mathrm{R}$ base, the fee could be deductible for the borrowing business, and taxable for the bank. As with other flows between the bank and the borrower, these taxes net out. In the case where both parties are liable to tax at the same rate, it should not matter whether the flows are included in the tax base or not. But if one of the parties has a taxable loss which does not receive an effective rebate then this is not true. For example, if the bank has a permanent taxable loss, for which it does not receive full relief, it may have an incentive to charge fees instead of interest, in order to generate higher taxable income against which its expenses could be offset. This raises the question of how other flows between the two parties should be treated. On the one hand, it may be beneficial to allocate the bank a higher taxable income to reduce the problem of taxable losses in the bank. But it may also be more straightforward not to discriminate between flows, and to leave all financial flows between the two parties outside the tax base.

A fourth issue concerns implementation. The R-base taxes only "real" flows, and so requires a distinction in the tax law between "real" and "financial" flows. This is required to counter incentives to disguise $R$ flows as $F$ flows, thus keeping them outside the $\mathrm{R}$ base. (Note though, that this only applies in cases where one of the two parties to a transaction is subject to tax at a different rate, or not subject to the tax, for example a tax exempt entity or an individual subject to an income tax; otherwise the taxes levied on both sides of the real transaction would net out.) On the other hand, under the R+F base, but not under the $\mathrm{R}$ base, the border between debt and equity requires policing. That is, as equity is not part of the tax base under an $R+F$ base, companies have an incentive to disguise inflows of debt as equity, and outflows of equity as debt. To counter this, rules must be introduced to prevent investors using hybrid financial instruments for tax planning - for example, having the main characteristics of equity, but disguised as debt for tax purposes, or vice versa. Both of these implementation issues are discussed further below.

\section{Transactions with individuals and tax-exempt entities}

A difference between the $R$ base and the $R+F$ base arises where a financial company engages in financial transactions with an individual, a tax exempt institution or another entity that is not subject to the tax. Applying the $R$ base to a bank would 
result in there being no tax at all; the bank engages in only financial transactions which would not be subject to tax, and the borrower would not be subject to this tax at all. To the extent that the bank may earn an economic rent from such transactions, an $\mathrm{R}$ base would therefore leave this economic rent untaxed. This would be similar to the case in the previous table, but with the borrower paying no tax.

This suggests that, even if an $\mathrm{R}$ base is used for transactions between taxable entities, financial companies should be subject to tax on their financial flows with any entities that are not subject to the same tax, and where the " $F$ " transactions do not therefore net out. ${ }^{53}$ An example of this is shown in Table 8 . This is the same as in the $R+F$ example above, except that the borrower is here assumed to be exempt from tax. In this case, in period 1 the bank receives deposits of 100 and lends 100 , with a net tax liability of zero. The borrower invests 100 in period 1 and earns 120 in period 2, but is not subject to tax. But in period 2 the bank pays tax on its profit, or economic rent in this case, measured as the difference between the 110 it receives and the 105 it pays out. The bank's economic rent of 5 is therefore taxed at $30 \%$, but the tax exempt's economic rent of 10 is untaxed.

Table 8. Treatment of Financial Flows under the $\mathrm{R}+\mathrm{F}$ base: tax exempt borrower

\begin{tabular}{|l|c|c|c|}
\hline & \multicolumn{2}{|c|}{ Pre-tax flows } & R+F base tax \\
\hline & Bank & Borrower & Bank only \\
\hline Period 1 & & & \\
\hline Bank receives deposit & 100 & & 30 \\
\hline Bank lends & -100 & 100 & -30 \\
\hline Investment by borrower & & -100 & 0 \\
\hline Total period 1 flows & 0 & 0 & \\
\hline Period 2 & & & 33 \\
\hline Return earned by borrower & & 120 & -31.5 \\
\hline Repayment with interest & 110 & -110 & 1.5 \\
\hline Repayment to depositor & -105 & & 10 \\
\hline Total period 2 flows & 5 & & \\
\hline
\end{tabular}

\footnotetext{
53 The combination of R-base treatment for B2B transactions and a form of $\mathrm{R}+\mathrm{F}$ treatment for $\mathrm{B} 2 \mathrm{C}$ transactions was proposed in the context of VAT by Huizinga (2002).
} 
Applying the $\mathrm{R}$ base for transactions between taxed entities, and applying the $\mathrm{R}+\mathrm{F}$ base to financial companies in their financial transactions with individuals or entities which are not subject to the tax therefore has the advantages of (a) excluding nonfinancial firms from the complications of implementing an $R+F$ base; while (b) taxing all of the economic rents of financial companies - either directly through the $F$ base applied to transactions with tax exempt entities, or indirectly by shifting the tax base to taxed borrowers.

Such a system would to some extent also lessen the problem of financial companies having a negative tax base, discussed above. Suppose again that the bank in the example above has labour costs of 5 . This reduces its economic rent to zero. In this case, the 5 of labour costs can be offset against the rent generated from lending to the tax exempt entity, implying that the bank does not have a negative tax base. Of course, it is still possible that the bank has a negative tax base; if, in the example, it has labour costs in excess of 5 .

Note that the financial company should be taxed on its net financial inflows from non-taxable entities, less all real costs (for example, for purchases of labour and other inputs) that it incurs. That is, it is not necessary to allocate its real costs to the activities in which it is directly taxed. That is because, as we have seen above, the financial company should get relief for its real costs even when it is transacting with taxable entities. As noted above, the problem of dealing with a negative tax base is partly a matter of perception as in aggregate the tax base in each period is equivalent to that under an $\mathrm{R}+\mathrm{F}$ for both financial and non-financial firms. If costs are fully allowed, then exactly the same tax would be generated if all taxable companies faced the $\mathrm{R}+\mathrm{F}$ base, and all entities would earn the same post-tax economic rent.

As noted, one of the main motivations for the netting approach to financial transactions is to simplify the tax system for nonfinancial firms by excluding their financial flows from the tax base. But this requires drawing a line between financial firms and other firms. Many nonfinancial firms engage in transactions with households that incorporate financial components, such as loans implicit in deferred payment arrangements. To the extent that these components increase the firm's tax base (by charging a high implicit interest rate in exchange for deferred payment), the nonfinancial firm might wish to explicitly separate the real and financial components, as the latter would not be taxable, and also to misstate the 
magnitudes of real and financial pieces, for example by overstating the interest rate charged on deferred payments and understating the initial purchase price. However, in this sense, non-financial companies would be earning an economic rent on their financial transactions with tax exempt consumers; to match the treatment of financial companies we would therefore want to tax them on such transactions. The easiest way to do so would be to include all expenditures and receipts from transactions of non-financial firms with tax exempt entities (such as individual customers) in the $\mathrm{R}$ base - even if they relate to charges for deferred receipt or payment, such as through leasing and hire purchase. In that case, there would be no need to extend formally the R+F approach to such firms.

In cases where real and financial activities are segregated, firms may already have separate operating units, which would allow the financial unit to be included in the financial regime. This separation would be possible for "nonfinancial" firms with significant levels of financial transactions. Such firms could then either treat the financial flows as if they were real (and include them under the R base), or they could treat them as financial, and include them under an $R+F$ base that applied to transactions with non-taxable entities and individuals. These two approaches would have the same tax consequences.

\section{International Considerations}

We now turn to the taxation of financial flows in an international context.

First, consider the effects of implementing a full R+F base on all taxed entities, and applied on a traditional origin basis. Suppose that a bank in country $A$ lends to a company in country $B$, and both countries operate a origin-based $R+F$ system. Then the bank would receive tax relief at $A^{\prime} s$ tax rate on its lending, while the company would be taxed at B's tax rate. Similarly, the company would get tax relief on its repayment of debt at B's tax rate, and the bank would be taxed at A's tax rate. Clearly then, extending the tax base to all financial cash flows does not eliminate the incentive to lend from a low tax country to a high tax country, nor, for transactions between related parties, does it eliminate the incentive to overstate the interest in such cases. ${ }^{54}$

\footnotetext{
${ }^{54}$ The same would be true under the Tax Calculation Account (TCA) base, discussed below and in the Appendix.
} 
If an $\mathrm{R}+\mathrm{F}$ tax were implemented in both countries, then instead it would be natural to have border adjustments for financial flows as well as real ones, in order to eliminate these incentives for profit shifting. In the case of financial flows, we treat the country of the borrower as being the place of "destination". An intuition for this approach is that the bank is essentially providing a service to the borrower, of the provision of funds for a period. This service is being "consumed" by the borrower, and so it is natural under the destination-based approach to apply the relevant taxes on financial flows in the location of the borrower.

An example of how the $\mathrm{R}+\mathrm{F}$ base would work if used in two countries is given in Table 9, which extends the previous example above by assuming that a bank in country $A$ lends to a company in country $B$. Assume that country $A$ has a $20 \%$ tax rate and country $B$ has a $30 \%$ tax rate. Under an $R+F$ tax base in both countries, country $A$ would not give relief at its tax rate on lending by the bank, nor would it tax the return that the bank earns, since it is not the destination country. Instead, all the tax effects from the cross-border lending itself would arise in country B. Suppose, as in the example above, that the company in B wants to invest 100 , on which it expects to earn a return of $20 \%$. The bank in $A$ is willing to lend 100 at an interest rate of 10 . In this case, country $B$ would both give relief on the initial bank lending and tax the funds received by the bank, both at $\mathrm{B}^{\prime}$ s tax rate. These taxes net out. But, the net cost to the bank of lending 100 is only 70, since it receives tax relief in B. In order to raise 70, it must issue 87.5 in gross deposits, on which it will pay tax in $A$ at $20 \%$ of 17.5 . In period 1 , then, net cash flows are zero for both the bank and the company. The overall value of the investment to the bank and the company therefore depends only on net cash flows in period 2. But, country A will have raised 17.5 in tax revenue in period 1 , while country $B$ would have a net 30 reduction in tax revenue in period 1 , due to the immediate expensing of the investment by the company. So the overall value of tax revenue to each government requires an aggregation of period 1 and period 2 flows.

In period 2, the company earns a gross return of 120 - on which it pays tax of 36 - and repays the bank 110 . The company receives tax relief of 33 on the repayment, and the bank pays tax of 33 - again these taxes net out. The bank then repays its depositor at $5 \%$ on the initial deposit, and receives tax relief on that repayment at $20 \%$ in country A. Given that the bank and the company both have zero net cash flows in period 1, the net effect is that the bank again earns a net economic rent of $3.5(18.1+18.4-33)$, 
and the company again earns a net economic rent of $7(10-3)$. This is the same as in the previous example of a single country with a tax rate of $30 \%$. To identify the period 2 values of net tax receipts, we gross up the period 1 taxes at $5 \%$ and add them to the period 2 values. The total value in period 2 terms of tax levied is again 4.5. However, in this case, this tax is collected entirely in country B - the destination country. The two tax effects in country $A$ - taxing the deposit in period 1 and giving relief for the repayment of the deposit with interest in period 2 - net to zero.

Table 9. Treatment of International Financial Flows under the $R+F$ base

\begin{tabular}{|c|c|c|c|c|c|c|}
\hline & \multicolumn{2}{|c|}{ Pre-tax flows } & \multicolumn{2}{|c|}{ Tax in A (20\%) } & \multicolumn{2}{|c|}{ Tax in B $(30 \%)$} \\
\hline & $\begin{array}{c}\text { Bank in } \\
\text { A }\end{array}$ & $\begin{array}{c}\text { Borrowe } \\
r \text { in } B\end{array}$ & $\begin{array}{c}\text { Bank in } \\
\text { A }\end{array}$ & $\begin{array}{c}\text { Borrowe } \\
\text { r in B }\end{array}$ & $\begin{array}{c}\text { Bank } \\
\text { in A }\end{array}$ & $\begin{array}{c}\text { Borrowe } \\
r \text { in } B\end{array}$ \\
\hline Period 1 & & & & & & \\
\hline $\begin{array}{l}\text { Bank in A } \\
\text { receives deposit }\end{array}$ & 87.5 & & 17.5 & & & \\
\hline Bank lends & -100 & 100 & & & -30 & 30 \\
\hline $\begin{array}{l}\text { Investment by } \\
\text { borrower }\end{array}$ & & -100 & & - & & -30 \\
\hline $\begin{array}{l}\text { Total period } 1 \\
\text { flows }\end{array}$ & -12.5 & 0 & 17.5 & 0 & -30 & 0 \\
\hline Period 2 & & & & & & \\
\hline $\begin{array}{l}\text { Return earned } \\
\text { by borrower }\end{array}$ & & 120 & & & & 36 \\
\hline $\begin{array}{l}\text { Repayment with } \\
\text { interest }\end{array}$ & 110 & -110 & & & 33 & -33 \\
\hline $\begin{array}{l}\text { Repayment to } \\
\text { depositor }\end{array}$ & -91.9 & & -18.4 & & & \\
\hline $\begin{array}{l}\text { Total period } 2 \\
\text { flows }\end{array}$ & 18.1 & 10 & -18.4 & 0 & 33 & 3 \\
\hline $\begin{array}{l}\text { Net value of } \\
\text { taxes (in period } 2 \\
\text { values) }\end{array}$ & & & 0 & 0 & 1.5 & 3 \\
\hline
\end{tabular}

Shifting the tax base of the financial firm to the place of destination has two consequences. First, the incentive to lend from a low tax country to a high tax country is eliminated, so that it is not possible to shift profits using flows of debt and interest. For example, even if the bank were located in a tax haven it would make no difference to the tax liability of either party. 
Second, since the taxes on financial flows net out in each period, this is equivalent to implementing an $\mathrm{R}$ base for these financial transactions. This is exactly the same as in the case of purely domestic transactions; the R-base example above would also apply to a foreign bank lending to a domestic company, with border adjustments and hence a destination base. Intuitively this also mirrors the case of imports of goods and services; for these we noted that since the taxation of imports netted out with the deduction for the cost of the input, it would be possible to ignore imports purchased by taxable entities altogether. The $R$ base can be seen as the equivalent for financial transactions. Since the tax flows in the $R+F$ destination base cancel out when the financial transactions are between taxable entities, then again they can simply be ignored. For financial transactions, this again returns us to the $\mathrm{R}$ base.

That is, for all financial transactions between taxable entities, border adjustments could be implemented by simply excluding cross-border financial flows from the tax system. Therefore the conclusion reached for financial flows between financial and non-financial firms in a domestic setting - to simply use the $R$ base - also holds in an international setting. The example can be used to consider the case of an $R$ base, shown in Table 10. In this case, there would be no net tax levied in country $A$, since in that example there are only financial flows. ${ }^{55}$ In country $B$, there would be tax relief of 30 for the investment undertaken there in period 1, and a tax of 36 on the total return to that investment in period 2. All the financial flows would be untaxed. In order to finance that investment, the company has to borrow 70 from the bank. As under the $\mathrm{R}+\mathrm{F}$ base in the previous, the period 2 value of the tax liability (evaluated at a mark-up rate of 5\%) would be 4.5 , the company would earn an economic rent of 7 (43-6), and the bank would earn an economic rent of 3.5.

Applying the $\mathrm{R}$ base for financial transactions with non-financial companies would require financial companies to determine whether their financial transactions were with taxable entities or not. However, it would alleviate their need to distinguish between domestic and foreign businesses in their transactions, as all such financial transactions would now be excluded from the tax base, not just those with foreign businesses.

\footnotetext{
${ }^{55}$ In the example, there would be no net tax revenue even if there were also a tax on financial flows with tax exempt depositors since depositors are assumed to be paid a rate of interest equal to the bank's discount rate.
} 
Table 10. Treatment of International Financial Flows under the $\mathbf{R}$ base

\begin{tabular}{|l|c|c|c|c|}
\hline & \multicolumn{2}{|c|}{ Pre-tax flows } & \multicolumn{2}{c|}{ Tax in B (30\%) } \\
\hline & $\begin{array}{c}\text { Bank in } \\
\text { A }\end{array}$ & $\begin{array}{c}\text { Borrower } \\
\text { in B }\end{array}$ & $\begin{array}{c}\text { Bank in } \\
\text { A }\end{array}$ & $\begin{array}{c}\text { Borrower } \\
\text { in B }\end{array}$ \\
\hline Period 1 & & & & \\
\hline Bank in A receives deposit & 70 & & & \\
\hline Bank lends & -70 & 70 & & \\
\hline Investment by borrower & & -100 & & -30 \\
\hline Total period 1 flows & 0 & -30 & 0 & -30 \\
\hline Period 2 & & & & 36 \\
\hline Return earned by borrower & & 120 & & \\
\hline Repayment with interest & 77 & -77 & & 36 \\
\hline Repayment to depositor & 73.5 & & & \\
\hline Total period 2 flows & 3.5 & 43 & & \\
\hline
\end{tabular}

Note that the application of a DBCFT in an international setting brings to the fore another reason for adopting an $\mathrm{R}$ base for domestic transactions. If financial flows are ignored in an international context but not in a purely domestic context, this would cause difficulties with respect to the treatment of cross-border sales of existing debt securities in secondary markets, where the original issuer need not be aware of the change in ownership. Suppose for example, that domestic company A borrowed from domestic company $B$, which subsequently sold the loan to foreign company $C$; in this case $C$ would pay $B$ the value of the loan and $B$ would pass on to $C$ all interest received from $A$. Since the initial loan was within the same domestic country, under an $R+F$ base the amount lent would be taxable for $A$ and deductible for $B$, and interest payments would be deductible for $A$ and taxable for $B$. All of $B$ 's dealings with $C$ (the proceeds from selling the loan to $C$ and delivery of the subsequent interest payments to $C$ would be untaxed in the domestic country because of border adjustments. That is, B would continue to pay tax on the loan's interest even after selling the loan to C, just as in the case where $B$ borrowed separately from $C$ and kept the loan to $A$ rather than selling the original loan to $C$. On the other hand, if $A$ borrowed from foreign lender D, which subsequently sold the loan to domestic company $E$, border adjustments would exclude all flows from the domestic tax base, including those between $A$ and $D$ and those between $D$ and $E$. This discussion suggests that there would be considerable benefits in leaving both domestic and cross-border financial flows between tax-paying companies out of the tax base altogether, as would happen if the $R$ base were applied. 
A final issue is that also faced in a domestic setting - how to tax cross-border lending by a financial company to individuals or entities which are not subject to the tax. To align their treatment when borrowing from either domestic or foreign banks, then it would be necessary to apply border adjustments in these cases too. That is, we would need to tax flows from and to the foreign bank at the domestic tax rate, with a deduction on lending and a tax on the repayment of principal and interest. As in the purely domestic case, these financial flows between financial institutions and these taxpayers do not net out. In effect, then, in an international setting a destination-based $R+F$ base would need to be applied for financial flows between financial institutions and these taxpayers.

We discuss further implementation issues below. In practice, cross-border loans by individuals should not be a major issue for most households, most of whose financial transactions are with domestic businesses, although it could be more important for wealthy households.

\section{Unilateral Adoption}

So far we have considered the treatment of financial flows in a setting where the DBCFT is adopted by all the countries concerned. But suppose that only one country - country A - adopted the DBCFT on an R base for transactions between taxed entities, and on an $\mathrm{R}+\mathrm{F}$ base for transactions with non-taxed entities. ${ }^{56}$ Suppose that all other countries maintained a traditional approach, taxing interest received and giving relief for interest paid, both on an origin basis. What would the incentives for borrowing and lending, and the location of each?

First, suppose that an affiliate of a multinational in country A lent to an affiliate located in country $B$. Then, irrespective of the identity of the borrower, there would be no tax levied in $A$, even under the $R+F$ base, since $A$ would not be the destination country in this case. In country $B$, relief would be given in the usual way on the interest paid to $A$ on the loan. Relative to the existing system, this makes $A$ appear like a tax haven: interest paid from $B$ to $A$ receives tax relief in $B$, but would not be taxed in $A$. This would clearly give an incentive for multinationals to locate

\footnotetext{
${ }^{56}$ A question arises in this case as to whether and how to differentiate borrowing from foreign "taxable" and "non-taxable" entities, neither of which would be subject to a DBCFT in their home countries. The consequences of each are discussed in the context of $R+F$ treatment.
} 
outbound lending in a country operating a destination base, whether an R base or $R+F$ base applied to such financial flows. (This may give rise to country $B$ using CFC rules to combat profit shifting out of $B$ ).

What of the reverse position? Suppose that the multinational instead lent from an affiliate in $B$ to an affiliate in $A$ ? Then under the $R$ base treatment, the financial flows would be ignored in country $A$. The treatment under an $R+F$ base in $A$ would depend on how the foreign entity is treated. If it is treated as "taxable" under the DBCFT, then the borrower would be taxed in the receipt of the loan, while the lender would receive tax relief. Similarly, the repayment of the loan with interest would be taxable in the hands of the recipient, but the borrower would receive tax relief. These tax effects would exactly cancel out, so that in this case, the R-base and $R+F$ base would be equivalent, with no net tax effects in country $A$. In country $B$, however, the interest on the loan would be taxable. This situation would be akin to lending to a tax haven under the existing system; there would be no net tax in A, but $B$ would impose a tax on the receipt of the interest. In this case, there would clearly be an incentive for multinational companies to avoid lending from an affiliate in a non-DBCFT country to an affiliate in a DBCFT country.

Overall, then, if a DBCFT were adopted in only one country, that would introduce a strong incentive for companies to shift their borrowing to other countries that continue to impose a traditional source-based income tax. Any borrowing, domestic or international, by a company located in a country operating a DBCFT would be ignored; whilst borrowing by a company in a country operating a traditional originbased income tax will benefit from interest deductibility. As with the incentives for profit shifting discussed earlier, this incentive is present even with respect to foreign countries with very low source-based tax rates.

Treatment of financial services under the VAT cum payroll subsidy approach

The equivalence between a DBCFT and an appropriate VAT combined with a corresponding payroll subsidy can be readily extended to the treatment of financial services. To see this, since the treatment of labour costs is the same in the two cases, it suffices to focus only on the financial flows themselves 
In practice, financial services (other than those explicitly charged for as a fee) are commonly exempt under the VAT: that is, there is no charge on services provided but nor is there any credit of refund of VAT charged on inputs. This has been a longstanding source of dissatisfaction, as it implies some cascading of taxes on financial services used by registered businesses - and hence risk of production inefficiency and excludes from the tax base the value of services provided to final consumers.

The conceptual difficulty perceived in this area has been that of allocating the margin embedded in the pricing of financial services between the two side of the transaction, and hence to ensure smooth functioning of the credit mechanism - something that, importantly, is needed only in relation to final consumers: for services provided to registered businesses, the spilt is immaterial, since any VAT charged by the seller will be creditable for the buyer.

One solution to this problem, developed by Poddar and English (1997), is R+F-type cash-flow treatment of exactly the kind discussed above. And the reason it allocates the margin appropriately is analogous to that in which the $\mathrm{R}+\mathrm{F}$ treatment allocates rents across firms: taxing and crediting all flows between registered businesses means that the only revenue that remains reflect the margin enjoyed by consumers.

For financial transaction between businesses, this netting of payments is exactly as under the DBCFT described above - and so, just as an R-base was seen there to be adequate for the treatment of financial flows under a DBCFT, so under a VAT they might equally well be ignored. This would mean 'zero-rating' such transactions: that is, charging no tax on provision (as at present) but providing full refund for input taxes allocable to transactions with registered businesses. Some countries already do something approaching this.

In an international context, the argument above suggested R-base treatment would also be appropriate for transactions with taxable entities abroad. This corresponds in VAT terms to zero-rating. And that, indeed, is already the norm: financial services provided to non-residents are generally zero-rated. The primary difference between current international VAT arrangements and those required to replicate the DBCFT as described above is thus the need for cash flow treatment of transactions with nonregistered taxable persons and entities. 
Consideration of the cash flow approach in the context of the VAT led to the development of one means of implementation that does not require immediate taxation of principal amounts. Somewhat analogous to the ACE relief described above, this is the "tax calculation account", the basic idea of which is to defer tax liabilities on financial inflows until the deductions for the corresponding outflows arise. To compensate for the difference in timing, it would be necessary to markup the deferred tax period by period. We discuss this in more detail in the Appendix. Briefly, the reasons for keeping the cash flow approach mirror those for not choosing the ACE approach for real flows. First, it may be administratively simpler to net out the tax on lending and on borrowing, which would only occur under the full cash flow treatment. Second, it would be necessary to specify the appropriate rate of markup for the TCA. In principle, setting the wrong markup rate could lead to distortions to financial flows, although the size of such distortions are likely to be small if the error in setting the markup rate were also small. This issue is discussed further in the Appendix. 


\section{IMPLEMENTATION}

Each country contemplating the policy choices described above will have its own concerns and circumstances. These would include not only the initial state of its revenue administration and wider tax system, but its policy objectives in terms of such issues as the treatment of smaller enterprises, ${ }^{57}$ not-for-profits and pass through entities. There are, however, several generic issues to be faced. Some of these have been touched on above; the focus here is on others.

\section{Two Economically Equivalent Reforms}

Most of the discussion so far in this paper has concerned the possibility of implementing a DBCFT as a form of corporation tax. However, we have also emphasised that an economically equivalent reform would be to raise the rate of VAT, or introduce a VAT - here in either case having in mind an idealized VAT levied at a single rate on a broad base -- and reduce labour taxes by that same rate. We set out these two approaches first, and then discuss some of the details of each.

Starting with the first of these, the key elements needed to transform a typical corporation tax into a DBCFT would be to:

- Abolish relief for interest payments;

- Allow immediate expensing for all business expenses;

- Ignore the proceeds of exports in the country of export;

- Ignore imports purchased by taxable entities (or tax them but include in deductible costs);

- Introduce a tax on imports purchased by non-taxable entities, including individual consumers; and

- For financial companies, tax net financial inflows resulting from transactions with non-taxable entities.

\footnotetext{
${ }^{57}$ A number of countries tax smaller enterprises at a reduced corporate tax rate, generally rationalizing this as a response to difficulties they may face in borrowing. Not all find the case for a reduced rate within current corporate tax systems compelling, seeing a stronger case for supporting new rather than small enterprises (IMF, 2016b). Whether to apply such treatment under a DBCFT would, in any case, require close thought. A small exporter purchasing from larger domestic enterprises, for instance, would be disadvantaged by being entitled to rebate at a rate lower than that to which its suppliers' sales are subject.
} 
VATs observed in practice differ in two important ways from the idealized VAT envisaged in the equivalence relationship with a DBCFT proposition: they are typically not levied at a uniform rate on all goods and services, and they do not tax financial flows between financial companies and tax exempt entities or consumers. Bearing that in mind, the reforms needed to transform the corporate tax into the equivalent of a DBCFT through a VAT-based approach are to:

- Abolish corporation tax;

- Raise the rate of VAT - and, for close equivalence to a DBCFT, abolish multiple VAT rates where they exist;

- Reduce the tax rate on labour income by the same rate. We refer to this as a "payroll subsidy" to identify its net effect relative to existing taxes; this would not amount to a tax rebate unless the rate of subsidy exceeded existing tax rates on labour income.

- To tax the returns to financial companies, introduce a cash flow tax on transactions between financial companies and both non-taxable entities and individuals.

Under either approach, many anti-avoidance features of existing corporate tax systems could simply be repealed, since they would no longer be required. These include, for example, CFC rules, transfer pricing rules, loan relationship rules and patent box regimes.

While these two approaches are economically equivalent and yield the same revenue, their implementation would obviously be different. Consequently, there are advantages and disadvantages of each of the two approaches, which we address in the final part of this section. For the vast majority of countries that already have a VAT, its existence can be both an advantage and a disadvantage.

It can be an advantage because raising the rate of an existing tax, even substantially, does not generally amount to a radical rewriting of the tax system. Further, many of the design questions that arise in designing a DBCFT have already been addressed in the implementation of VATs. But it can be a disadvantage, because most existing VAT systems do not cope as well as one would hope with all of the issues that we discuss here in ways which appear preferable - for example, in the treatment of financial flows. Also, most VATs are marked by widespread exemptions and/or the application 
of differential rates. Raising only the standard rate of VAT and combining that with a payroll subsidy may then seem a relatively easy option, but it would not be economically equivalent to introducing a DBCFT; and nor would the equivalence results of Section 2 fully apply. The DBCFT route may then (subject to various caveats below) be more appealing.

It is important to recognize, in any case, that many of the design problems and implementation problems to be faced are much the same for the DBCFT and the VATbased approach. We have already seen this in relation to the treatment of financial services, and will see the point again below when discussing how to define 'destination.' Nor do all the administrative issues associated with a traditional corporate tax disappear. It remains necessary under both the DBCFT and VAT-based approach, for example, to distinguish between business and (non-deductible) personal expenditures.

Either direction of reform could be introduced gradually, potentially reducing the transition costs of moving to a new system. Clearly, in the case of the VAT plus payroll subsidy, it would be possible to gradually adjust the rates of the three taxes concerned. And for the DBCFT itself, it would be possible, for example, to gradually extend the proportion of exports and imports that are not taxed, thereby gradually introducing the destination basis; we describe this further below. Such gradual adjustment may reduce the transition costs of moving to a new system, although the period of time of transition would clearly be longer.

\section{Practical Issues}

Any new tax raises practical challenges, and creating a DBCFT by reforming the corporation tax is no different. Many issues, however, are familiar. Some are familiar because they relate to the cash-flow element of the tax and have been discussed, together with potential solutions, over many years. Others are familiar because they relate to the destination element of the tax and thus also arise in the context of existing VATs. A third group of issues are common to existing systems of business taxation. And fourth, there are some issues that are specific to this particular reform; these require more extensive consideration here. 
The difficulties in implementing the alternative approach, through increasing the rate of VAT and reducing the rate of payroll taxes, depends on whether a country already has experience of a VAT and payroll taxes. For countries which do not have a VAT, such as the US, many issues arise in the choice of determining the way in which the VAT is implemented - with the opportunity to learn from the best practices of others, for instance in maintaining a simple rate structure, minimizing exemptions and in the treatment of the financial sector. ${ }^{58}$ For countries that already have a VAT, it is straightforward to raise the standard rate, the difficulty with this being that the existing VAT may well not match the broad-based tax we have in mind here. On the payroll subsidy element, for developed countries it would be relatively straightforward to simply reduce their extensive payroll taxes. (Where payment of such taxes is linked to entitlement to future benefit, arrangements would need to made to secure those rights; but this has proved straightforward to do, for example in the case of payroll tax holidays). Most developing countries, however, do not have extensive payroll taxes, and the reach of taxes on wage income is often limited. Outright wage subsides would then be needed, posing significant administrative issues. For such countries, the most practicable route to a DBCFT-equivalent system is likely to be to adopt the DBCFT itself.

Against this background, we discuss practical issues under five main headings: the scope of the tax; the need to distinguish real from financial flows, and flows of debt from flows of equity; the treatment of taxable losses; identifying the place of destination; and methods of collection. In each case, we begin by analysing the case of a DBCFT and then consider how things would be different if the reform were instead shaped as a VAT with payroll subsidy.

\section{a. Scope}

Any tax on business profits has to contend with a number of questions relating to its scope. These include specifying which legal forms of business are to be subject to the tax, whether there is to be a minimum threshold below which businesses would be exempt and how such businesses would then be taxed. In setting the scope of the DBCFT, efficiency suggest that (i) the tax apply equally to all businesses, to avoid distortions to legal form or size, and also to avoid competitive distortions; and (ii)

\footnotetext{
${ }^{58}$ Conversely, of course, introducing a DBCFT while raising labour taxes can be a way of introducing a VAT; and perhaps with more chance of achieving these desirable ends than through the reform of an existing VAT.
} 
either to set the rate for closely held businesses at the personal income tax rate or adopt rules that require such businesses to treat an appropriate portion of their income as salary, so to avoid the incentive for individuals to declare labour income in the form of business profit (or vice versa, depending which tax rate is higher). (Of course, this potential problem exists under most current systems whenever there are different rates for personal and business income). ${ }^{59}$ It is also important to consider the administrative and compliance burden on small businesses and revenue authorities.

The scope of the tax on business profits varies between countries. In most, corporation tax is applied to all incorporated businesses. But this is not universal. In the US, for example, 'S corporations' are subject to pass-through treatment, under which profit is allocated to individual shareholders and is subject to personal income tax. ${ }^{60}$ By contrast, VAT is normally applied to all businesses over a certain size threshold, almost always defined in terms of turnover; the smallest businesses are not required to register for the tax because for them administrative and compliance costs would be disproportionate to the revenue at stake and potential distortions from their exemption.

Ultimately, the key choice here is that of the threshold between those businesses (whether or not they are incorporated) that would be subject to the DBCFT, and those that would not be. The latter could most probably be subject to pass-through treatment. ${ }^{61}$ Two questions arise in choosing the threshold. First, what should be the nature of the threshold: Should it be specified in terms, for instance, of having a certain number of investors, earning some level of profit or (like most VAT systems) having turnover above some level ${ }^{62}$ Second, at what level should that threshold be set?

\footnotetext{
${ }^{59}$ Crawford and Freedman (2010) and the Mirrlees Review (2011) propose to maintain the corporation tax for incorporated businesses only, but to introduce the combination of a rate of return allowance at the personal level, an allowance for corporate equity at the corporate level, and an alignment of rates to limit shifting between personal and corporate taxes.

${ }^{60}$ There are restrictions on which businesses can elect for $\mathrm{S}$ corporation status. For example, $\mathrm{S}$ corporations are allowed a maximum of 100 shareholders, who must be US citizens or residents.

${ }^{61}$ Since in most countries shareholders in closely held corporations must pay some tax on distributions of corporate profits, to avoid competitive distortions investors in unincorporated businesses should similarly be taxed on distributions if those businesses bear the same DBCFT tax rate as corporations. This has the advantage of minimising distortions in competition between businesses, and in choices of legal form for businesses above the threshold.

${ }^{62}$ It is worth pointing out that one can cover most business activity, or at least the activity of large businesses that operate in a manner similar to corporations, without covering most businesses, given
} 
The appropriate level of the threshold has been most extensively studied in relation to the VAT. This literature points to three main considerations. ${ }^{63}$ First, a lower threshold tends to raise more revenue. Acting in the opposite direction, administration and compliance costs rise the more firms lie above the threshold. Another though somewhat less clear-cut consideration is that the more businesses that do not face the DBCFT, the greater are likely to be competitive distortions between different types of companies. ${ }^{64}$ Businesses that are not subject to the DBCFT but are subject to pass-through treatment may be better or worse off than business subject to the DBCFT, depending on the relative rates of tax.

On balance, the best option may well be to follow the same approach as is standard under the VAT, and apply the DBCFT to all businesses over a certain (modest) size, measured by domestic sales. Indeed, an obvious and simple approach would be to set the threshold for the DBCFT at the same level as the VAT threshold. ${ }^{65}$ Clearly, this alignment of the scope of corporation tax with VAT also brings the two reform options closer together. For any given turnover threshold, the scope of the DBCFT would then coincide with that from instead using the VAT plus payroll subsidy approach. ${ }^{66}$

The question also arises as to whether businesses outside whatever scope is determined should be allowed to register for the tax voluntarily - which they may wish to do to an even greater extent than under current VATs, in order to claim rebates. Efficiency considerations argue that they should be; but this may need to be tempered

the size distribution of the business sector. For example, according to Auerbach (2010), in 2007 in the USA, 90 percent of all S corporations, accounting for 58 percent of all net income of $\mathrm{S}$ corporations, had at most two shareholders. Only 0.2 percent of the sector's returns, accounting for less than 8 percent of the sector's income, came from S corporations with more than 20 shareholders. So limiting the reform in the USA to those $S$ corporations with more than a few shareholders would have a minor impact on the sector as a whole.

${ }^{63}$ See Ebrill et al. (2001), Keen and Mintz (2004) and, on empirics, Liu and Lockwood (2016).

${ }^{64}$ Further considerations arise when noncompliance is accounted for: see Kanbur and Keen (2015).

${ }^{65}$ See though Kanbur and Keen (2015), who show there can be disadvantages in aligning thresholds for distinct taxes (in aggravating the bunching of taxpayers just below them).

${ }^{66}$ As part of their credit-invoice method VATs, approximately two-thirds of OECD countries allow small businesses to elect to be exempt from VAT. Because small businesses exempt from the credit-invoice method VAT cannot claim input credits, and purchases from small businesses do not provide input credits, exempting small businesses generally does not provide a significant distortive advantage to those businesses. A small business exemption is more problematic in a DBCFT or subtraction-method VAT, because purchases from exempt small businesses may still be deducted by registered traders (Grinberg (2010), 342-43). This last feature means that one of the incentive to register voluntarily under the invoice-credit VAT- to enable crediting of the input tax on the inputs of a supplier selling to registered businesses - will not apply under the DBCFT. 
by the costs and risk of controlling taxpayers who are a call upon rather than contributors to public funds.

\section{b. Real versus financial flows under an $R$ base, and debt $v$ equity under an $R+F$ base}

As set out above, a DBCFT would likely best be structured to have R-base treatment for all cash flows but with special rules for flows between a taxed financial company and non-taxable entities. This then requires rules to counter attempts to avoid taxation by disguising $\mathrm{R}$ flows as $\mathrm{F}$ flows.

It is important to note, however, that this avoidance opportunity does not arise when both parties to a transaction are subject to tax. In that case - as set out above - the cash flow tax liabilities that would arise on financial transactions under an $R+F$ base would net out. In such cases, the vendor's incentive to disguise R flows as $F$ flows would be countered by the purchaser's incentive to treat the whole price as an R flow. Whilst the portion of the $\mathrm{R}$ disguised as an $\mathrm{F}$ would not be included in a vendor's inflows, it would also not be included in a purchaser's outflows meaning the latter would not obtain the corresponding relief.

So the avoidance opportunity arises only where one of the two parties to a transaction is not subject to the tax (being a tax exempt entity, for example, or an individual subject to an income tax), where the two parties are subject to the tax at different tax rates, or if full loss relief is not available and one of the parties has a taxable loss.

Rules to differentiate real and financial flows in these cases would need to be supplemented by rules to differentiate between flows related to debt and equity in the case of applying the R+F base to transactions with tax exempt entities. As equity flows are not part of the tax base under an $\mathrm{R}+\mathrm{F}$ base, companies have an incentive to disguise debt as equity - for example, through the use of hybrid financial instruments - thus keeping financial payments out of the base entirely. But if the $R+F$ base is limited to transactions of financial companies with tax exempt entities and individuals, the importance of this distinction is equally limited. 
Turning to the alternative VAT based strategy, as discussed above, the starting point is that financial businesses are typically exempt from VAT; this means that they do not charge VAT on lending or other financial transactions, but neither are they permitted to reclaim VAT paid on inputs. It is generally recognised that this treatment is not ideal. The analysis above suggests that - as proposed for instance by Huizinga (2002) business-to-business financial transaction be zero-rated, while cash flow treatment (along $\mathrm{R}+\mathrm{F}$ lines) be applied for transactions with consumers or other non-taxable entities. In respect of financial transactions too, the VAT plus payroll subsidy approach could therefore be used to implement a reform which economically equivalent to a DBCFT; but this would require a significant reform of commonly-applied systems of VAT.

\section{c. Losses}

The issue of losses and negative tax bases arises in three contexts under the DBCFT.

\section{Domestic}

Because of immediate expensing, negative tax bases can arise under a cash flow tax even for successful companies operating in a purely domestic setting. Take for instance a rapidly growing company engaging in substantial capital investment in a particular year: immediate expensing of those investments could easily lead to a negative tax base, even if the company is projected to increase its revenue streams substantially as a result of its investment in the near future. If a cash flow tax is to be neutral with respect to marginal investment decisions, full relief, or some alternative equivalent, should be given. Box 2 illustrates this key point.

As this example highlights, providing relief for losses is critical to attaining one of key attractions of cash flow taxation. However, relief in the form of immediate refund could prove politically unattractive. Permitting the taxable loss to be carried forward indefinitely with an interest markup ${ }^{67}$ does not in practice perfectly replicate the effect of immediate refunds, because of the possibility of company insolvency before the loss carried forward is actually used - but it does significantly alleviate it. Other

\footnotetext{
${ }^{67}$ Bond and Devereux $(1995,2003)$ address the question of what interest rate is needed in the presence of risk; they show that a markup at the risk-free rate is sufficient as long as the amount carried forward is certain to be paid to the company. Where it is not, then a higher rate would be required that covered that specific risk.
} 
possible solutions include: allowing the marketing of unused tax benefits associated with these activities, although this is not without its pitfalls, as the U.S. experience with "Safe Harbor Leasing" from the early 1980s illustrates; ${ }^{68}$ allowing taxable losses to be used in the context of mergers with profitable businesses; or allowing taxable losses to be set against other taxes paid by the business, such as payroll taxes. ${ }^{69}$

\section{Box 2. The Treatment of Losses}

The table below illustrates the simple case of a company that makes an investment of 100 in period 1, and earns a total return of 120 in period 2. Suppose that the rate of interest is $5 \%$, and that the company uses this rate of return to compare cash flows in the two periods. In this case, the 100 of investment in period 1 is equivalent to an outflow of cash in period 2 of 105. The economic rent earned by the investment in period 2 terms is therefore 15: the inflow of 120 less the markedup outflow of 105.

Now consider alternative ways of taxing this investment, with a tax rate of $30 \%$. Under a classic R-base cash flow tax, the initial investment would be immediately expensed, and so the tax payable in period 1 would be -30 . If necessary, this could take the form of a payment of 30 to the company by the government. The period 2 value of this to the company, given the $5 \%$ interest rate, would be 31.5 . The tax in period 2 would be 36 . The period 2 value of the two elements of the tax combined is therefore 4.5 . This is $30 \%$ of the economic rent, as is intended under a cash flow tax.

Now suppose that no rebate is available for the first period tax loss, but that it is instead simply carried forward to set against second period income. In this case, the tax base in period 2 would be 20 - the return of 120 less the carried forward loss of 100 - and so the tax would be 6 . This tax base (20) exceeds the economic rent earned (15). The investment will still be attractive to the investor, since after-tax profit is positive; but this would not have been the case, for instance, had the project been only marginally profitable in the absence of tax. This effect can be removed by marking up the loss by the interest rate as it is carried forward. In this case, the loss brought forward into period 2 would be 105, and the period 2 value of the tax would revert to $4.5 .^{70}$ Note that this is similar in effect to the case where an allowance is given for the cost of finance, as under an allowance for corporate

\footnotetext{
${ }^{68}$ See Warren and Auerbach (1982).

${ }^{70}$ This treatment has been proposed by, among others, the President's Advisory Panel (2005) and Carroll and Viard (2012).
} 
equity (ACE). For suppose that relief for the cost of the investment is not available until the return is made, but that there is relief in period 2 for the opportunity cost of finance; this is the foregone interest of 5 . In this case, the tax in period 2 is again $4.5,30 \%$ of the economic rent.

Illustration of properties of alternative treatment of losses

\begin{tabular}{|l|c|c|c|}
\hline & $\begin{array}{c}\text { Period 1 cash } \\
\text { flows }\end{array}$ & $\begin{array}{c}\text { Period 2 } \\
\text { cash flows }\end{array}$ & $\begin{array}{c}\text { Period 2 value } \\
\text { of } \\
\text { investment/tax }\end{array}$ \\
\hline $\begin{array}{l}\text { Capital investment, and total } \\
\text { return on investment }\end{array}$ & -100 & +120 & 15 \\
\hline $\begin{array}{l}\mathrm{R} \text { base tax with immediate } \\
\text { expensing, and full refund }\end{array}$ & -30 & 36 & 4.5 \\
\hline $\begin{array}{l}\mathrm{R} \text { base tax with immediate } \\
\text { expensing, and loss carried } \\
\text { forward }\end{array}$ & 0 & 6 & 6.5 \\
\hline $\begin{array}{l}\mathrm{R} \text { base tax with immediate } \\
\text { expensing, and loss carried } \\
\text { forward with interest markup } \\
\text { at } 5 \%\end{array}$ & 0 & 4.5 & \\
\hline
\end{tabular}

The example in Box 2 does not include labour costs, so the position under a VAT would be exactly as the first row in the table, with an immediate rebate of expenses. An analogous problem thus arises, as is very familiar, under a VAT. It may seem rather different in kind, since the VAT rebate is as a refund of VAT paid on capital inputs purchased. If the firm purchasing the capital equipment had no sales in that period, then it can generally reclaim the VAT paid on that input. Combining this with a reduction in the tax on wages and salaries would yield exactly the same outcome as permitting a rebate for the negative tax charge under a cash flow tax. It may appear different because the negative VAT charge can be seen as a rebate of VAT already paid. However, the same broad principle also applies to a cash flow corporation tax charge, since the supplier would also be subject to the cash flow tax. 


\section{International}

This issue of losses becomes more pronounced in an international setting, because the DBCFT taxes domestic sales less domestic expenses. So if a company produces in country $A$ and sells all its produce in country $B$, then it would have a negative tax base in country $A$. That is because the expenditure incurred to provide goods and services both domestically and for export is set against revenues from domestic sales and not exports. The tax bases of firms that export a high percentage of their goods or services can thus easily be negative. This could be a permanent state of affairs for such firms, in which case they will not be helped by carrying losses back or forward with interest. In such situations, the options of allowing refunds in respect of negative tax bases or cross-crediting against other taxes, such as payroll taxes, become more important. $^{71}$

If full relief were not provided the DBCFT would be likely to distort location decisions, losing an important aspect of its efficiency properties. To see this, consider the simple example in Table 11. Suppose that there are two countries, both operating a DBCFT, and both at the same tax rate, 30\%. A company has expenditure of 100 and sales of 120. (For simplicity, in this example assume that these flows happen in the same period). Its sales are in country $A$, but it can choose whether to produce in A or B. If it chooses to produce in $A$ then its tax base will be 20 and it will pay tax of 6 . If it chooses to produce in $B$ it will have a taxable loss in $B$ of 100 , and a taxable income in $A$ of 120 . If it receives a full refund in respect of the 100 of expenditure in $B$ then its location decision will not depend on tax; it will continue to pay tax of 6 . But if it receives no relief for the cost in $B$, then its tax base effectively becomes 120 , with a tax liability of 40 . Thus the treatment of losses in this case can be highly important for location decisions. ${ }^{72}$

\footnotetext{
${ }^{71}$ Under this latter approach, it is of course conceivable that credit due on losses may exceed the amount of other taxes remitted. And where tax administration is weak, reliable cross-crediting may be difficult to achieve.

${ }^{72}$ Note that the distortion does not come from differences in the treatment of losses: as in this example, a common but imperfect treatment distorts because some locations choices imply losses while others do not. The symmetric treatment of losses is also important for the effects on exchange rates, or prices under a fixed exchange rate regime, which, discussed above, are important for the efficiency properties of the DBCFT.
} 
Table 11. Illustration of effects of not receiving relief for expenditure

\begin{tabular}{|l|c|c|}
\hline & Produce in A & Produce in B \\
\hline Expenses in A & -100 & - \\
\hline Expenses in B & - & -100 \\
\hline Sales in A & 120 & 120 \\
\hline Tax base in A & 20 & 120 \\
\hline Tax base in B with full offset & - & -100 \\
\hline Tax base in B with no offset & - & 0 \\
\hline Total tax base with full offset & 20 & 20 \\
\hline Total tax base with no offset & 20 & 120 \\
\hline
\end{tabular}

There may be some doubt as to the willingness of countries to provide relief for expenditure incurred to produce revenue which they will not tax. However, three considerations should be kept in mind.

First, some countries have been willing to accept similar situations under the existing corporate tax system. For example, they have allowed relief for interest expenses on domestic loans used to equity finance the activities of foreign subsidiaries even when they exempt the dividends paid back from the foreign subsidiaries. The UK has presented such generous treatment of interest expense as a competitive advantage. ${ }^{73}$

Second, under a DBCFT countries would also tax domestic sales by foreign firms. So while countries may find themselves giving relief for expenditure incurred to produce revenue they will not tax, they may also collect tax revenues reflecting business expenditure for which they did not provide relief. From the country's perspective, the revenue consequences should be seen at an aggregate level, where an element of quid pro quo is at play, and not at the level of an individual company. In aggregate the net effect on the tax base hinges on the relative magnitude of exports and imports; this question was addressed in the previous section.

Third, competitive forces provide countries with a powerful incentive to provide full relief under a DBCFT. Failure to do so would place them at a competitive disadvantage in attracting business activities relative to countries which give full relief. To take the

${ }^{73}$ HM Treasury (2010). 
example in Table 11 above, if $B$ did not provide relief for the expenditure, the company would have an incentive to locate its activities in A. This would be true for most companies that aimed to supply an export market. In fact, the opposite problem might arise in that countries which are particularly keen on attracting certain activities, such as manufacturing, would have an incentive to compete by going beyond full relief through overly generous expensing rules or interest rates on losses carried forward.

Note that the same issues arise if reform takes the form of a VAT plus a payroll subsidy. A domestic firm that exports all of its output is generally permitted to reclaim any VAT that is has paid on inputs. In general, this rebate would be less than that required under a DBCFT since the VAT does not give relief for labour costs. But combining the VAT with a payroll subsidy would automatically also give the same relief for labour costs as under the DBCFT. Under normal VAT rules then, the VAT plus payroll subsidy approach would be equivalent to giving a full rebate for the taxable loss described above. There is perhaps a difference in perception here, in that the VAT rebate itself would be separate, and is generally seen as a repayment of VAT paid at an earlier stage of production. But, given the matching reduction in taxes on (or subsidy to) wages and salaries, the VAT plus payroll subsidy approach would of course be equivalent to giving a full rebate under the DBCFT.

\section{Financial institutions}

We saw merit above in applying an $\mathrm{R}$ base for financial firms when transacting with non-financial firms subject to tax at the same rate, and an $\mathrm{R}+\mathrm{F}$ base when transacting with non-taxable entities. That is, financial companies would be taxed on their net financial inflows from non-taxable entities, less all real costs (for example, for purchases of labour and other inputs) that it incurs. As described at length above, all real costs would be allowable against tax, since in effect the economic rent generated from lending to taxed businesses is taxed in the hands of the borrower. An advantage of this approach is that non-financial firms do not need to keep track of their financial flows for tax purposes (although they do need to distinguish real and financial flows). But, if a financial firm does not have a sufficient and positive net cash flow from tax exempt entities and individuals, then it may be left with a negative tax base. This does not mean that it is not profitable, nor that tax has not been levied on the total profit generated; it simply means that some important income will be taxed in the hands of 
the borrower, not the lender. At an aggregate level, total tax collected will be the same as under an $\mathrm{R}+\mathrm{F}$ base applied to all businesses.

Just as above, efficiency requires financial companies that find themselves in this position to be refunded in respect of their negative position. From an implementation perspective this might raise some concerns. In particular, again it is possible that countries may be unwilling to pay tax refunds to financial firms in a taxable loss position. As with the problem of international flows in the previous subsection, this taxable loss may be permanent, and so cannot be dealt with through carrying the loss back or forwards, even with an interest mark-up.

A different solution to dealing with the taxable losses of financial companies therefore needs to be found: while the problem mirrors that of dealing with the taxable losses of exporters discussed above, it is amplified by the non-taxation of some domestic transactions by financial institutions. One approach might be to allow taxable losses of financial institutions to be transferred to non-financial businesses that are in a taxpaying position. This could in principle be achieved, in effect, by making the netting of business-to-business financial transactions optional, although introducing this option would complicate the system and could introduce distortions if transferability still left financial institutions in loss positions. ${ }^{74}$ Another approach would again be that of allowing financial institutions to offset their taxable losses under this cash flow tax against other taxes to which they are subject, for example, payroll taxes or special taxes levied on the financial sector.

In an international setting, with banks lending to non-domestic tax exempt entities, the position is the same as for other exporters; relief should be given for costs incurred domestically, even though there may be no taxable income to match those costs. This would be true if the $R+F$ base were applied generally, as well as under the mixed $\mathrm{R}$ and $\mathrm{R}+\mathrm{F}$ approach discussed here. Once again, it is necessary to find a way to reimburse the loss, in order to preserve economic efficiency. Again, this could be done by crediting the taxable loss against other taxes, such as payroll taxes or special taxes levied on the financial sector.

\footnotetext{
${ }^{74}$ In that case, financial firms would have an incentive to net flows that would have increased taxes on nonfinancial firms (e.g., payments to them by financial firms) and not to net flows that reduce taxes on nonfinancial firms (e.g., payments by them to financial firms), as there would be immediate tax consequences of these choices only for the nonfinancial firms involved.
} 
As noted above, VAT is generally levied only on real flows, and not financial flows. The combination, however, of a VAT reformed along the lines described above - zerorating $\mathrm{B} 2 \mathrm{C}$ and applying cash flow treatment to $\mathrm{B} 2 \mathrm{~B}$ transactions - and payroll subsidy would be equivalent to giving an immediate tax rebate under the DBCFT.

\section{d. Destination}

A central element in the implementation of a DBCFT would be operationalizing the relevant notion of "destination", identifying "exports" to be taken out of tax and "imports" to be brought in. In setting about this, the design of a DBCFT can usefully draw on experience under the VAT, for which notions of destination have been most fully discussed and developed. ${ }^{75}$

The OECD defines the destination principle as the "principle whereby internationally traded services and intangibles should be subject to VAT in their jurisdiction of consumption" (OECD, 2013). ${ }^{76}$ This clearly identifies the VAT notion of "destination" as a proxy for the place of consumption. However, the fundamental principle underlying the DBCFT is not that the tax should be levied in the place of consumption per se, but that the tax rate that is ultimately important should be that of a place of relative immobility; and a more immobile location than the place of consumption is likely to be the place of residence of the consumer, rather than the place of consumption.

The use of proxies is a near-universal feature of VAT systems, recommended by the OECD as an appropriate way in which to establish destination. The complexity of this approach varies. For example, the European VAT system has been particularly complex, with determination of the place of taxation of any specific transaction depending on such issues as: whether the supply involved goods or services; the identity of the acquirer, in particular whether she is a VAT registered person; the timing of the supply; the location of the supply; and the nature of the goods or services supplied. ${ }^{77}$

\footnotetext{
${ }^{75}$ It has to be said, however, that there has been endless scope for confusion in the VAT context in the both the usage of the term 'destination' and the notion of 'consumption': see Keen and Hellerstein (2009-10).

${ }^{76}$ OECD (2013), as above, p. 3.

${ }^{77}$ See de la Feria (2009).
} 
For the purposes of implementing a DBCFT, Devereux and de la Feria (2014) analyse in some detail the use of proxies for "destination" in VAT. Taking into account the aim of having a relatively immobile tax base, they recommend the use of the customer location proxy, defined as "the location, residence, or place of business of the customer, the person to whom the seller has a contractual legal obligation to supply the goods." They propose this for goods and services and for both business-tobusiness (B2B) and business-to-consumer (B2C) transactions.

For cross-border trade in goods, they argue that this would achieve a definition of destination in most cases with minimal complexity. ${ }^{78}$ It is possible that in some cases the customer location proxy might not lead to taxation in the country of destination. But for simplicity, and as long as this does not create administrative difficulties or opportunities for avoidance or fraud, using a single proxy avoids many of the common problems in existing systems of VAT.

Establishing the destination of services can be more complex, ${ }^{79}$ and a challenge for VAT design is how to identify the destination of services in the absence of physical flows. ${ }^{80}$ For implementing a DBCFT, Devereux and de la Feria (2014) argue that the customer location proxy would work well in most cases, and this is indeed recommended by the $\mathrm{OECD}$ as the main rule for $\mathrm{B} 2 \mathrm{~B}$ transactions. In $\mathrm{B} 2 \mathrm{~B}$ transactions this proxy can be easily applied by reference to the business agreement, though it can be problematic where the customer has establishments in more than one jurisdiction and the services are used by one or more establishments under an internal recharge arrangement. $^{81}$

B2C transactions in cross-border services create difficulties for administrative obligations, since applying the customer location proxy may result in a requirement to register for VAT purposes in every jurisdiction where services are received. If these administrative obligations can be overcome then the customer location could work as a good proxy for establishing destination, without any need to use further proxies. However, Devereux and de la Feria propose that in exceptional circumstances the

\footnotetext{
${ }^{78}$ Using this proxy alone may not lead to taxation in the country of consumption. For example, when an intermediary buys goods to be consumed by someone else, other proxies are often used in conjunction, such as the place of effective use or enjoyment. This however is not a problem for the DBCFT since destination is not proxy for consumption.

${ }^{79}$ The OECD has issued several guidelines on how to apply the destination principle to services, culminating in the release of a complete set in 2015; see OECD (2013).

${ }^{80}$ Keen and Hellerstein (2009-10).
} 
proxy used vary from the customer location proxy, particularly for B2C transactions where that rule would be too burdensome. This will be the case where the supply of services requires the physical presence of both the supplier and the customer in some way, such as restaurant services, concerts and sports events. In such cases they recommend the place of performance of a service or the place of location of a good as a proxy, since the destination is readily identifiable as the place where the supply is carried out, and applying the customer location proxy could potentially lead to distortive results and fraud, as well as being burdensome for suppliers. However, the use of this proxy in these cases creates a minor distortion between cross-border shopping - where the place of location proxy is used - and e-commerce - where the customer location proxy would be used.

Of course, if the the reform took the form of an increase in the rate of an existing VAT combined with a payroll subsidy, then it would appear to be more straightforward simply to use the existing VAT law, rather than to introduce reforms to the definition of "destination." Increasingly, however, countries are in any case likely to model their rules around the OECD Guidelines. For countries that do not currently have a VAT, such as the US, then there is no such easy route to increasing use of the destination principle. In these cases, the discussion above about how to define destination holds irrespective of the form the reform takes.

\section{e. Collection}

The collection of the DBCFT raises some challenges. A DBCFT could leave B2B transactions between entities taxed in distinct countries out of the tax base entirely. Exports would be zero-rated, and as discussed above, imports purchased by businesses could be ignored (either taxed but with relief, or neither). So the challenges for collecting revenue under a DBCFT relate primarily to cross-border B2C transactions. (And, of course, one issue is to be able to identify whether a transaction is $\mathrm{B} 2 \mathrm{~B}$ or $\mathrm{B} 2 \mathrm{C})$.

The DBCFT would tax imports purchased by individual consumers and non-taxable entities. Where a customer purchases a good or service directly from a business in another country, a tax should be levied at the rate of the destination country. Two options open to the destination country are to collect the tax from the exporting company or from the consumer. The former appears to be the more realistic option, 
although not without difficulties of its own, especially in the absence of fiscal borders, or for digital products, as is clear from the operation of VAT. These are, in any case, issues that already arise under the VAT.

The DBCFT could be seen as a tax on the net domestic inflows of domestic businesses, plus a tax on non-resident businesses that export to domestic consumers. This is a familiar problem for VAT systems based on destination. In principle it would be necessary for the company to register for tax in the country into which it is exporting the good or service; this is difficult to administer for relatively small exporters, particularly when the good or service can be downloaded electronically, or where there are no customs operations at borders. The exporter must also identify the location of its customer, and whether the customer is a business or a consumer. The tax authority must identify companies from around the world that export to its country, and also guard against any opportunities for fraud if final consumers pretend they are businesses. For this purpose, gathering information from intermediaries such as credit card and other payment companies will be an important enforcement tool, both for a DBCFT and a VAT.

One innovation in the EU that could be applied amongst cooperating countries is a "one stop shop", as proposed by Devereux and de la Feria (2014) and the Gaspar Committee (2014). Under such a system a company selling into several separate countries would need to register in only one; in many cases that is likely to be the origin country from which the company exports. The tax authority in that country would administer the DBCFT at the rate of the country to which the good or service is exported. Going beyond what has yet been achieved in Europe, one could envisage a clearing arrangement at the aggregate level, where payments are made between tax authorities in recognition of the appropriate recipient of the tax. Such cooperation would clearly create a significant administrative simplicity relative to the case in which the exporter is required to register and pay tax in each country in to which it exports.

It is worth noting that the one-stop-shop approach makes the need to deal with a negative tax base in a specific business less likely. Suppose, for example, that a business in $A$ exports to a consumer in $B$. The tax authority in $A$ charges tax on sales in $B$ at B's tax rate, net of relief for expenses incurred in $A$ and $A$ 's tax rate. As long as the business is profitable overall, and tax rates are not too different, then it is likely that the business will have a positive tax base in $A$. The implicit negative tax base in $A$ 
would be netted against similar implicit negative tax bases in $B$ for business in $B$ exporting to $A$, and would be cleared at an aggregate level.

The implementation of collecting a tax on imports by individuals is broadly similar whether the DBCFT is introduced in its corporation tax form, or as a VAT plus payroll subsidy.

\section{f. Tax Treaties and the WTO}

It is unclear whether the DBCFT would be considered as an income tax which would fall within the ambit of bilateral tax treaties. If so, then it would clearly be in violation of a number of provisions of such treaties. In this case, the two parties to the treaty may be able to renegotiate the treaty provisions, but if that were not possible, it is possible that the treaty would be terminated. If the DBCFT was considered not to fall within the ambit of the treaty, then the treaty could continue, but the non-DBCFT country would not be obliged to give any credit against tax levied by the DBCFT country.

It is also critically important to recognize that many (e.g., Schön, 2016) have argued that a DBCFT would be inconsistent with WTO rules. The primary concern with the DBCFT under WTO rules relates to the deduction for labour costs. Compare the purchase of an imported good with that of an identical domestically-produced good. The labour costs of the latter are allowed as a deduction in the country of sale - since in this case it is also the country of origin. But no comparable relief is given in the country of sale for the labour costs incurred in producing the imported good. It is argued that this makes the DBCFT incompatible with WTO rules.

In contrast, a credit-invoice VAT on a destination-basis is unambiguously WTO compliant since it does not give relief for either form of labour costs. So too, of course is reducing payroll taxes, or even instituting a general wage subsidy. The VAT cum payroll subsidy equivalent to the DBCFT would thus face no prospect of legal challenge in the WTO or any need for re-negotiation of trade agreements (President's Advisory Panel, 2005; Hufbauer, 1996; Schön, 2016.)

To economists, of course, this legal distinction between two equivalent tax structures makes no sense. The only difference in practical terms is that the relief for labour 
costs is given inside the DBCFT, but as a standalone measure under the VAT cum payroll subsidy approach. But there may also be equivalent intermediate approaches under which the relief for labour costs is more of a standalone measure. As we have argued above in Section II (1)(a), due to exchange rate movements or wage and price adjustments under a fixed exchange rate, neither reform option creates any discrimination in favour of domestically produced goods. A reduction in payroll taxes does encourage domestic production to the extent that it lowers domestic production costs; but this is true of any reduction in source-based tax rates.

The fact remains, however, that because WTO compliance is determined by interpretation of existing legal agreements and not by virtue of economic equivalences, it is unlikely that a DBCFT, drafted with an integrated wage subsidy, would, if challenged, be held to be WTO compliant. Without a separation of the wage component, a renegotiation of those agreements would therefore be likely to be required.

\section{g. Transitional issues}

Moving to a cash flow tax base would introduce well-known transitional issues of implementation. For example, there is a question of how to treat the preenactment basis in existing assets, including plant, equipment, and inventory. Proponents of cash-flow taxes have typically recommended deductions over time for a business's pre-enactment basis. ${ }^{82}$ Similar issues arise in how to treat pre-enactment debt, pre-enactment loss carry-forwards and unused business tax credits. We do not explore these here, though none seems unmanageable.

Consideration also needs to be given to the possible announcement effects of reform. In a fixed exchange rate regime context, for example, with sticky wages one might expect forward purchasing, particularly of durables, in advance of the expected increase in consumer prices ${ }^{83}$ (which then may itself be to some degree brought forward). With a flexible exchange rate, the nominal appreciation from BTA would be

\footnotetext{
${ }^{82}$ President's Advisory Panel (2005) (who proposed a five-year period for deduction of basis) and Carroll and Viard (2012) (who proposed a 10-year period).

${ }^{83}$ Evidence of such effects can be found in Danninger and Carare (2008) and Büttner and Madzharova (2016).
} 
expected to start in advance of implementation, bringing forward balance sheet and wealth effects and influencing trade as well.

As noted above, either the DBCFT or the VAT plus payroll subsidy approach could be introduced gradually. But perhaps most easily, it could be introduced by a gradual increase in the rate of VAT (although this would be subject to concerns about multiple rates), a gradual reduction in the payroll tax and a gradual reduction in the rate of existing corporation tax. Indeed, in the absence of any fundamental reform, it seems likely that trends in this direction - similar to the fiscal devaluation discussed above will continue, prompted by strong underlying economic forces of competition between countries. While this process continues, VATs and corporate income taxes could co-exist. For countries that wish to maintain corporate income taxes - to counter the possibility that a DBCFT would serve to shelter capital income of the business's investors, or because they would like to continue to tax domestic production - then increasing VAT and reducing corporate income taxes and payroll taxes may be an attractive alternative to the full implementation of a DBCFT.

\section{h. Other issues in comparing the two approaches}

A variety of other issues also arise in choosing between the introduction of a DBCFT and the alternative approach of increasing the rate of an idealized VAT (or introducing a new one).

The credit-method VAT has an advantage over the DBCFT approach, which is similar to that of a subtraction-method VAT, since it has now been put in place in more than 160 countries worldwide. There is therefore considerable experience of how they work best. By contrast, there is little experience with a DBCFT approach, or with the subtraction-method VAT. ${ }^{84}$ As noted above, there is an advantage of the invoicecredit approach where small businesses, non-profit organizations, and/or state and local governments are exempt from the tax. ${ }^{85}$

\footnotetext{
${ }^{84}$ Many analysts have described the Japanese VAT as a subtraction-method tax. See, e.g., Bartlett (2009), Grieco and Hufbauer (2005). Alan Schenk and Oliver Oldman more accurately describe it as a "credit-subtraction" VAT, as opposed to the "sales-subtraction VAT"; see Schenk and Oldman (2007).

${ }^{85}$ See, for example, Grinberg (2010), Weisbach (2000) and McLure $(1997,1987)$.
} 
The invoice-credit approach also has an advantage where it is desired to have more than one rate, although in general, the presumption would be that the DBCFT should apply at the same rate for all goods. Indeed, one problem with relying on existing VATs is that they generally exclude many goods and services from the tax base. This would suggest that the VAT approach would be more attractive in countries which have a broader VAT base or no VAT at all.

For a country without an existing VAT that wants to continue to tax production and so does not wish to eliminate its source-based corporate tax, adopting a DBCFT would seem to require two business tax regimes, which could be administratively burdensome. However, if the country were willing to convert its existing corporate tax to a cash flow tax that is only partially destination-based, administrative burdens would be minimised. For example, if a country adopted a cash flow tax system generally with a $25 \%$ tax rate and provided that exports were $40 \%$ zero-rated for the tax and imports were $40 \%$ non-deductible, then the system would be equivalent to a DBCFT at $10 \%$ plus a source-based cash flow tax on production at $15 \%$. (Indeed one could envisage this a structure for gradual movement towards a full DBCFT, gradually increasing that $40 \%)$. The tax on production would be similar to a corporate income tax, but by allowing expensing and disallowing interest deductions, it would avoid the distortions created by debt financing and depreciation deductions.

A VAT, unlike the DBCFT, taxes consumption out of all wage income, including high wage income, as well as out of rents from capital. In some countries, political barriers may limit high tax rates on wage income. In such instances, coupling a VAT with payroll tax relief for low and moderate wage earners may achieve more progressivity than a DBCFT with wages taxed only at the individual level.

In the previous section we discussed the problem that exporting firms would have a negative tax liability under the DBCFT, and possible approaches to this. A lack of refunds in a DBCFT might create distortions in the locations of both production and corporate residence. The problem is reduced in the case of a combination of VAT and payroll subsidy. But as noted above, the VAT and payroll subsidy approach would in effect be equivalent to giving an immediate rebate for taxable losses under the corporation tax or subtraction-method VAT approach. In effect the potential tax "loss" observed in the DBCFT due to wage expenses not being matched by income is incorporated into the reduction in the payroll tax. 
Unlike a VAT, a DBCFT - and a payroll subsidy or tax reduction - must identify and give relief for wages. As noted above, this is generally problematic for all taxes on the income derived by closely held businesses, in that wages must be distinguished from non-deductible payments to the firm's suppliers of capital. In general, this problem cannot be solved completely without some form of rules that distinguish between returns to capital and returns to the labour of capital providers. In the U.S., for example, the Internal Revenue Service has tried to limit wages to "reasonable compensation." Since partnerships and other flow-through entities are typically taxed on their capital and labour income, this problem has not arisen for such entities. But where business income is taxed at substantially lower rates than wage income, rules distinguishing the two are necessary. This is true regardless of whether a country adopts a DBCFT or VAT with payroll subsidy; rather it is a function of whether after either form of tax is adopted, wages are taxed at higher rates.

One further issue is how the two alternative approaches would be treated in financial accounting. The treatment of credit-invoice VATs is well settled: the tax has no effect on earnings reported to shareholders. But the financial accounting of the DBCFT is uncertain. It could be treated as an operating expense. Alternatively, it could be treated as an income tax. The latter treatment could lead to serious distortions if behaviour is driven by profits as reported in the financial accounts, due to the innumerable timing differences between a cash flow tax and an income tax.

\section{Final Thoughts}

The DBCFT is an unfamiliar concept to many, and its economic consequences especially the impact of the border tax adjustment on exchange rates and prices - are difficult to explain and to understand. Yet the destination element of the DBCFT is taken from the VAT, which was also once unfamiliar - and may continue to be in countries that have not yet adopted one. We believe that there is a need for clear, dispassionate analysis of the complex issues involved in discussing international tax and its potential reform; that is what this paper - and the book of which it is to be part - has tried to provide. 


\section{References}

Andrews, W.D. (1974) "A Consumption-Type or Cash Flow Personal Income Tax", Harvard Law Review, 1113, 1148-165.

Auerbach, A.J. (2010) "A Modern Corporate Tax", The Center for American Progress / The Hamilton Project.

Auerbach, A.J. and D. Holtz-Eakin (2016), "The Role of Border Adjustments in International Taxation," American Action Forum, available at https://www.americanactionforum.org/research/14344/

Auerbach, A.J. M.P. Devereux and H. Simpson (2010) "Taxing Corporate Income", in J. Mirrlees et al (eds.), Dimensions of Tax Design: The Mirrlees Review, Oxford: Oxford University Press, 837-893.

Auerbach, A.J. and M.P. Devereux (2015) "Cash flows taxes in an international setting", Oxford University Centre for Business Taxation.

Avi-Yonah, R. and K. Clausing (2016) "Problems with Destination-Based Corporate Taxes and the Ryan Blueprint, University of Michigan Law and Economics Research Paper No. 16-029.

Bartlett, B. (2009) "Support the VAT", Oct. 23 available at http://forbes.com/2009/10/22/republicans-value-added-tax-opinionscolumnists-bruce-bartlett.html.

Benedek, D., R. de Mooij, M. Keen and P. Wingender (2016), "Estimating VAT Pass Through," IMF Working Paper 15/214.

Boadway, R. and N. Bruce (1984) "A general proposition on the design of a neutral business tax", Journal of Public Economics 24, 231-239.

Boadway, R. and M. Keen (2010) "Theoretical perspectives on resource tax design", in P. Daniel, M. Keen and C. McPherson eds. The Taxation of Petroleum and Minerals: Principles, Problems and Practice, Abingdon: Routledge.

Bond, S.R. and J. Xing (2015) "Corporate taxation and capital accumulation: Evidence from sectoral panel data for 14 OECD countries", Journal of Public Economics 130, 15-31.

Bond, S.R. and M.P. Devereux (1995) "Generalised R-based and S-based taxes under uncertainty", Journal of Public Economics 87, 1291-1311.

Bond, S.R. and M.P. Devereux (2002) "Cash flow taxes in an open economy", Centre for Economic Policy Research Discussion Paper Series, Discussion Paper 3401.

Bond, S.R. and M.P. Devereux (2003) "On the design of a neutral business tax under uncertainty", Journal of Public Economics 58, 57-71

Brown, E.C. (1948) "Business Income Taxation and Investment Incentives", in Income, Employment and Public Policy, Essays in Honor of Alvin H. Hansen.

Büttner, T. and B. Madzharova (2016) "Pre-announced VAT Increases and the Sales of Consumer Durables." Unpublished.

Carroll, R. and A.D. Viard (2012) Progressive Consumption Taxation: The X-Tax Revisited, Washington DC: AEI Press.

Crawford, C. and J. Freedman (2010) "Small business taxation" in Mirrlees Committee eds., Dimensions of Tax Design, Oxford: Oxford University Press.

Crawford, I., M. Keen and S. Smith (2010) "VAT and excises" pp. 275-362 in Mirrlees Committee eds., Dimensions of Tax Design, Oxford: Oxford University Press. 
Crivelli, E., R. de Mooij and M. Keen (2016) "Base erosion, profit shifting and developing countries", FinanzArchiv, 72, pp. 268-301.

Cui, Wei (2015) "Destination-Based Cash-Flow Taxation: A Critical Appraisal", University of British Columbia.

Danninger, Stephan, and Alina Carare (2008) "Inflation smoothing and the modest effect of VAT in Germany." IMF Working Paper, WP/08/175.

De Meza, D., B. Lockwood, and G.D. Myles, (1994), "When are origin and destination regimes equivalent?" International Tax and Public Finance, Vol. 1, pp. 5-24.

de Mooij, R. (2011) "Tax biases to debt finance: assessing the problem, finding solutions", IMF Staff Discussion Note.

de Mooij, R. and M. Keen (2013) "Fiscal devaluation and fiscal consolidation: the VAT in troubled times", pp. 443-485 in Alberto Alesina and Francesco Giavazzi (eds.), Fiscal Policy After the Crisis (Chicago: University of Chicago Press).

Devereux, M.P. (2012) "Issues in the Design of Taxes on Corporate Profit", National Tax Journal 65(3), 709-730.

Devereux, M.P. and R. de la Feria (2014) "Defining and implementing a destinationbased corporate tax", Oxford University Centre for Business Taxation Working Paper 14/07.

Devereux, M.P. and R. Griffith (1998) "Taxes and the location of production: evidence from a panel of US multinationals", Journal of Public Economics 68.3, 335-367.

Devereux, M.P., B. Lockwood and M. Redoano (2008) "Do countries compete over corporate tax rates?" Journal of Public Economics 92.5-6, 1210-1235.

Devereux, M.P., G. Maffini and J. Xing (2016) "Corporate tax incentives and capital structure: new evidence from UK tax returns", Oxford University Centre for Business Taxation Working Paper 16/01.

Devereux, M.P. and P. Birch Sorensen (2006) "The Corporate Income Tax: international trends and options for fundamental reform" European Commission Economic Papers 264.

Doidge, C. and A. Dyck (2015) "Taxes and corporate policies: evidence from a quasinatural experiment", Journal of Finance 70(1), 45-89.

Ebrill, L. M., M. Keen, J-P. Bodin, and V. Summers (2001), The Modern VAT, Washington, DC: International Monetary Fund.

European Economic Advisory Group (2007) The EEAG Report on the European Economy, Chapter 5, 121-32, Munich: CESifo Group.

Feldstein, M. and P. Krugman (1990), "International Trade Effects of Value-Added Taxation," pp. 263-282 in A. Razin and J. Slemrod (eds.) Taxation in the Global Economy (Chicago: University of Chicago Press).

de la Feria, R. (2009) "Place where the supply/activity is effectively carried out as an allocation rule: VAT v. Direct taxation" in M. Lang et al (eds.), Value Added Tax and Direct Taxation - Similarities and Differences, Amsterdam: IBFD, 961-1014.

Gaspar Committee (2014) Report of the Commission Expert Group on Taxation of the Digital Economy, chaired by Vitor Gaspar, Brussels: European Commission.

Genser, B. and G. Schulze (1997), "Transfer pricing under an origin-based VAT system," FinanzArchiv, Vol. 54, pp.51-67. 
Graetz, M.J. (1979) "Implementing a Progressive Consumption Tax", Harvard Law Review 92, 1575-1661.

Grieco, P. and G.C. Hufbauer (2005) "America Badly Needs a Value-Added Tax", Financial Times, Apr. 21.

Graham, J.R. (2003) "Taxes and corporate finance: a review", Journal of Financial Studies 16 (4), 1075-1129

Grinberg, I. (2010) "Where Credit is Due: Advantages of Credit-Invoice Method for a Partial Replacement VAT", NYU Tax Law Review 63, 316-358.

Hall, R. E. and D.W. Jorgenson (1967), "Tax policy and investment behaviour", American Economic Review 57, 391-414.

Heider, F. and A. Ljungqvist (2015) "As certain as debt and taxes: estimating the tax sensitivity of leverage from state tax changes", Journal of Financial Economics $118,684-712$.

H.M. Treasury (2010) The Corporate Tax Road Map, London: H.M. Treasury.

Hufbauer, G.C. and C. Gabyzon (1996) Fundamental Tax Reform and Border Tax Adjustments, Peterson Institute for International Economics.

Huizinga, H. (2002) "A European VAT on financial services", Economic Policy 17, 498534.

IMF (2016a) "Tax Policy, Leverage and Macroeconomic Stability" October, available at https://www.imf.org/external/np/pp/eng/2016/100716.pdf.

IMF (2016b) "Acting Now, Acting Together" Fiscal Monitor, April, available at http://www.imf.org/external/pubs/ft/fm/2016/01/fmindex.htm.

Kaldor, N. (1955) An Expenditure Tax, London: George Allen \& Unwin.

Kanbur, R. and M. Keen (2015) "Reducing informality", Finance and Development 52-4.

Keen, M. and W. Hellerstein (2009), "Interjurisdictional Issues in the Design of a VAT", Tax Law Review 63, 359-408.

Keen, M. and J. Mintz (2004) "The optimal threshold for a value-added tax", Journal of Public Economics 88, 559-576.

Keen, M. and R.A. de Mooij (2016) "Debt, taxes, and banks", Journal of Money, Credit and Banking, 48, pp.5-33.

Keen, M. and S Lahiri (1998) "The Comparison between Destination and Origin Principles under Imperfect Competition," Journal of International Economics 45, 323-350.

Kleinbard, E. (2007) "Rehabilitating the Business Income Tax", Hamilton Project Discussion Paper 2007-9.

Liu, L. and B. Lockwood (2016) "VAT notches, voluntary registration and bunching: Theory and UK evidence", Oxford University Centre for Business Taxation Working Paper 16/10.

Lockwood, B. (1993) "Commodity Tax Competition under Destination and Origin Principles" Journal of Public Economics 53, 141-162.

Lockwood, B. (2001) "Tax Competition and Tax Co-ordination under Destination and Origin Principles: a Synthesis", Journal of Public Economics 81, 279-319.

Meade Committee (1978) The Structure and Reform of Direct Taxation, report of a committee chaired by Professor J.E. Meade, London: George Allen \& Unwin.

Merrill, P. (2011) VAT Treatment of the Financial Sector, Tax Analysts, 163-185 
Mirrlees Committee (2011) "Reforming the Tax System for the 21st Century: The Mirrlees Review", Oxford: oxford University Press.

OECD (2013) OECD International VAT/GST Guidelines, Draft Consolidated Version, Paris: OECD.

Patel, E. and J. McClelland (2017) "What would a cash flow tax look like for US companies? Lessons from a historical panel", Office of Tax Analysis Working Paper 116.

Poddar, S. and M. English (1997) "Taxation of financial services under a value-added tax: applying the cash-flow approach", National Tax Journal 50.1, 89-111.

President's Advisory Panel on Federal Tax Reform (2005) "Simple, fair and pro-growth: Proposals to Fix America's Tax System".

Schenk, A. and O. Oldman (2007) Value-added Tax: A Comparative Approach, Cambridge Tax Law Series. New York, NY: Cambridge University Press.

Schenk, A. (1995) "Japanese Consumption Tax After Six Years: A Unique VAT Matures", Tax Notes 899 (Nov. 13, 1995)

Schön, W. (2016) "Destination-Based Income Taxation and WTO Law: A Note. In: H. Jochum , P. Essers, M. Lang, N. Winkeljohann and B. Wiman (eds.) Practical Problems in European and International Tax Law - Essays in Honour of Manfred Mössner. Amsterdam, IBFD, 429-451.

Warren, A.C. and A.J. Auerbach (1982) "Transferability of Tax Incentives and the Fiction of Safe Harbor Leasing", Harvard Law Review 95. 8, 1752-1786.

Zangari, E. (2014) "Addressing the Debt Bias: A Comparison between the Belgian and the Italian ACE Systems", European Commission Taxation Papers 44-2014. 


\section{Appendix. Cash flow treatment v mark-up treatment for financial flows}

In our discussion of the treatment of financial flows, we mentioned the possibility of defer tax liabilities on financial inflows until the deductions for the corresponding outflows arise. The deferred values would be identified in a "tax calculation account" (TCA). ${ }^{86}$

We illustrate this idea in the Table below. In the table a company borrows 100 from a bank in period 1; the tax rate is $30 \%$. Under the $\mathrm{R}+\mathrm{F}$ base, the bank would receive tax relief of 30 , and the borrower would pay tax of 30 . In period 2, borrower repays 110 , including 10 of interest. Again, under the $\mathrm{R}+\mathrm{F}$ base, the bower would receive tax relief of 33 , and the bank would pay tax of 33. Under the TCA, however, the period 1 liabilities would be deferred and carried forward to period 2. Assuming a markup of $5 \%$ on the carried forward amounts, the bank would have a brought forward deferred asset in period 2 of 31.5, and the company would have a brought forward deferred liability of 31.5. These would be set against the notional tax payment of 33 for the bank, and notional tax relief of 33 for the company. This implies that the only tax liabilities would be in period 2; a tax charge of 1.5 for the bank offset by tax relief of 1.5 for the company.

Treatment of Financial Flows under the TCA

\begin{tabular}{|l|l|c|c|}
\hline \multicolumn{2}{|l|}{} & $\begin{array}{c}\text { Period 1: } \\
\text { Lending }\end{array}$ & $\begin{array}{c}\text { Period 2: } \\
\text { Repayment with } \\
\text { interest }\end{array}$ \\
\hline \multirow{2}{*}{ Pre-tax cash flows } & Bank & -100 & +110 \\
\cline { 2 - 4 } & Borrower & 100 & -110 \\
\hline \multirow{2}{*}{$\begin{array}{l}\text { Carried forward deferred } \\
\text { tax asset or liability }\end{array}$} & Bank & 30 & - \\
\cline { 2 - 4 } Tax & Borrower & -30 & - \\
\hline & Bank & 0 & -1.5 \\
\cline { 2 - 4 } & Borrower & 0 & 1.5 \\
\hline
\end{tabular}

More generally, the bank's tax liability in period 2 would be positive or negative depending on whether the interest rate on borrowing was less than, or greater than, the rate of markup. As long as the rate of markup matched the company's discount

\footnotetext{
${ }^{86}$ See Poddar and English (1997), Merrill (2011).
} 
rate, then this approach would generate exactly the same net present value of tax payments as the $\mathrm{R}+\mathrm{F}$ base.

The timing of the TCA approach more closely resembles that of the current approach to interest deduction and taxation, with no immediate tax consequences of borrowing or lending. Since we are advocating R-base treatment for financial flows between tax-paying entities, the application of TCA treatment would only be on transactions between a financial company and tax exempt entities and individuals. in the example above with a tax exempt entity, the bank would simply pay tax of 1.5 in period 2.

An advantage of the F approach over the TCA approach is that it removes the need to determine the appropriate interest rate to use for the markup in the TCA account. As is clear from the example above, the rate of markup is crucial in determining the size of the total tax associated with borrowing, including whether the tax is positive or negative. If the rate is set too low, then there could be an effective subsidy to the use of debt. Correspondingly, if it is set too high, then the tax would partly fall on normal income as well as economic rent. 


\title{
Oxford University Centre for Business Taxation Working Paper series recent papers
}

\author{
WP16/14 Joachim Englisch, John Vella and Anzhela Yevgenyeva The Financial Transaction \\ Tax proposal under the enhanced cooperation procedure: Legal and practical \\ Considerations
}

WP16/13 Michael Devereux Measuring corporation tax uncertainty across countries: Evidence from a cross-country survey

WP16/12 Andreas Haufler and UIf Maier Regulatory competition in capital standards with selection effects among banks

WP16/11 Katarzyna Habu Are financing constraints binding for investment? Evidence from natural experiment

WP 16/10 Li Liu and Ben Lockwood VAT notches, voluntary registration and bunching: Theory and UK evidence

WP 16/09 Harry Grubert and Roseanne Altshuler Shifting the burden of taxation from the corporate to the personal level and getting the corporate tax rate down to 15 percent

WP 16/08 Margaret K McKeehan and George R Zodrow Balancing act: weighing the factors affecting the taxation of capital income in a small open economy

WP 16/07 Michael P Devereux and Li Liu Stimulating investment through incorporation

WP16/05 Tobias Böhm, Nadine Riedel and Martin Simmler Large and influential: firm size and governments' corporate tax rate choice?

WP16/04 Dhammika Dharmapala The economics of corporate and business tax reform

WP 16/03 Rita de la Feria EU VAT principles as interpretative aids to EU VAT rules: the inherent paradox

WP 16/02 Irem Guceri Will the real R\&D employees please stand up? Effects of tax breaks on firm level outcomes

WP 16/01 Giorgia Maffini, Jing Xing and Michael P Devereux The impact of investment incentives: evidence from UK corporation tax returns

WP 15/33 Anzhela Cédelle Enhanced co-operation: a way forward for tax harmonisation in the EU?

WP 15/32 James Mahon and Eric Zwick Do experts help firms optimise?

WP 15/31 Robin Boadway, Motohiro Sato and Jean-François Tremblay Cash-flow business taxation revisited: bankruptcy, risk aversion and asymmetric information 
WP 15/30 Martin Simmler Do multinational firms invest more? On the impact of internal debt financing and transfer pricing on capital accumulation

WP 15/29 Daniel Shaviro The crossroads versus the seesaw: getting a 'fix' on recent international tax policy developments

WP 15/28 Zhonglan Dai, Douglas A Shackelford, Yue (Layla) Ying and Harold H Zhang Do companies invest more after shareholder tax cuts?

WP 15/27 Martin Ruf and Julia Schmider Who bears the cost of taxing the rich? An empirical study on CEO pay

WP 15/26 Eric Orhn The corporate investment response to the domestic production activities deduction

WP 15/25 Li Liu International taxation and MNE investment: evidence from the UK change to territoriality

WP 15/24 Edward D Kleinbard Reimagining capital income taxation

WP 15/23 James R Hines Jr, Niklas Potrafke, Marina Riem and Christoph Schinke Inter vivos transfers of ownership in family firms

WP 15/22 Céline Azémar and Dhammika Dharmapala Tax sparing agreements, territorial tax reforms, and foreign direct investment

WP 15/21 Wei Cui A critical review of proposals for destination-based cash-flow corporate taxation as an international tax reform option

WP 15/20 Andrew Bird and Stephen A Karolyi Governance and taxes: evidence from regression discontinuity

WP 15/19 Reuven Avi-Yonah Reinventing the wheel: what we can learn from the Tax Reform Act of 1986

WP 15/18 Annette Alstadsæter, Salvador Barrios, Gaetan Nicodeme, Agnieszka Maria Skonieczna and Antonio Vezzani Patent boxes design, patents, location and local R\&D

WP 15/17 Laurent Bach Do better entrepreneurs avoid more taxes?

WP 15/16 Nadja Dwenger, Frank M Fossen and Martin Simmler From financial to real economic crisis: evidence from individual firm-bank relationships in Germany

WP 15/15 Giorgia Maffini and John Vella Evidence-based policy-making? The Commission's proposal for an FTT

WP 15/14 Clemens Fuest and Jing Xing How can a country 'graduate' from procyclical fiscal policy? Evidence from China? 
WP 15/13 Richard Collier and Giorgia Maffini The UK international tax agenda for business and the impact of the OECD BEPS project

WP 15/12 Irem Guceri and Li Liu Effectiveness of fiscal incentives for R\&D: quasiexperimental evidence

WP 15/11 Irem Guceri Tax incentives and R\&D: an evaluation of the 2002 UK reform using micro data

WP 15/10 Rita de la Feria and Parintira Tanawong Surcharges and penalties in UK tax law

WP 15/09 Ernesto Crivelli, Ruud de Mooij, Michael Keen Base erosion, profit-shifting and developing countries

WP 15/08 Judith Freedman Managing tax complexity: the institutional framework for tax policy-making and oversight

WP 15/07 Michael P Devereux, Giorgia Maffini and Jing Xing Corporate tax incentives and capital structure: empirical evidence from UK tax returns

WP 15/06 Li Liu and Ben Lockwood VAT notches

WP 15/05 Clemens Fuest and Li Liu Does ownership affect the impact of taxes on firm behaviour? Evidence from China.

WP 15/04 Michael P Devereux, Clemens Fuest and Ben Lockwood The taxation of foreign profits: a unified view

WP 15/03 Jitao Tang and Rosanne Altshuler The spillover effects of outward foreign direct investment on home countries: evidence from the United States

WP 15/02 Juan Carlos Suarez Serrato and Owen Zidar Who benefits from state corporate tax cuts? A local labour markets approach with heterogeneous firms

WP 15/01 Ronald B Davies, Julien Martin, Mathieu Parenti and Farid Toubal Knocking on Tax Haven's Door: multinational firms and transfer pricing

WP14/29 Anzhela Yevgenyeva The taxation of non-profit organizations after Stauffer

WP 14/28 Peter Birch Sørensen Taxation of shareholder income and the cost of capital in a small open economy

WP 14/27 Peter Birch Sørensen Taxation and the optimal constraint on corporate debt finance

WP 14/26 Johannes Becker, Ronald B Davies and Gitte Jakobs The economics of advance pricing agreements 
WP 14/25 Michael P Devereux and John Vella Are we heading towards a corporate tax system fit for the 21st century?

WP 14/24 Martin Simmler Do multinational firms invest more? On the impact of internal debt financing on capital accumulation

WP 14/23 Ben Lockwood and Erez Yerushalmi Should transactions services be taxed at the same rate as consumption?

WP 14/22 Chris Sanchirico As American as Apple Inc: International tax and ownership nationality

WP 14/19 Jörg Paetzold and Hannes Winner Taking the High Road? Compliance with commuter tax allowances and the role of evasion spillovers

WP 14/18 David Gamage How should governments promote distributive justice?: A framework for analyzing the optimal choice of tax instruments

WP 14/16 Scott D Dyreng, Jeffrey L Hoopes and Jaron H Wilde Public pressure and corporate tax behaviour

WP 14/15 Eric Zwick and James Mahon Do financial frictions amplify fiscal policy? Evidence from business investment stimulus

WP 14/14 David Weisbach The use of neutralities in international tax policy

WP 14/13 Rita de la Feria Blueprint for reform of VAT rates in Europe

WP 14/12 Miguel Almunia and David Lopez Rodriguez Heterogeneous responses to effective tax enforcement: evidence from Spanish firms

WP 14/11 Charles E McLure, Jack Mintz and George R Zodrow US Supreme Court unanimously chooses substance over form in foreign tax credit

WP 14/10 David Neumark and Helen Simpson Place-based policies

WP 14/09 Johannes Becker and Ronald B Davies A negotiation-based model of taxinduced transfer pricing

WP 14/08 Marko Koethenbuerger and Michael Stimmelmayr Taxing multinationals in the presence of internal capital markets

WP 14/07 Michael Devereux and Rita de la Feria Designing and implementing a destination-based corporate tax

WP 14/05 John W Diamond and George R Zodrow The dynamic economic effects of a US corporate income tax rate reduction 
WP 14/04 Claudia Keser, Gerrit Kimpel and Andreas Oesterricher The CCCTB option - an experimental study

WP 14/03 Arjan Lejour The foreign investment effects of tax treaties

WP 14/02 Ralph-C. Bayer Harald Oberhofer and Hannes Winner The occurrence of tax amnesties: theory and evidence

WP14/01 Nils Herger, Steve McCorriston and Christos Kotsogiannisz Multiple taxes and alternative forms of FDI: evidence from cross-border acquisitions 